\title{
Identification and characterization of VapBC toxin-antitoxin system in Bosea sp. PAMC 26642 isolated from Arctic lichens
}

\author{
HYERIN JEON, ${ }^{1,3}$ EUNSIL CHOI, ${ }^{1,2,3}$ and JIHWAN HWANG ${ }^{1,2}$ \\ ${ }^{1}$ Department of Microbiology, Pusan National University, Busan 46241, Republic of Korea \\ ${ }^{2}$ Microbiological Resource Research Institute, Pusan National University, Busan 46241, Republic of Korea
}

\begin{abstract}
Toxin-antitoxin (TA) systems are genetic modules composed of a toxin interfering with cellular processes and its cognate antitoxin, which counteracts the activity of the toxin. TA modules are widespread in bacterial and archaeal genomes. It has been suggested that TA modules participate in the adaptation of prokaryotes to unfavorable conditions. The Bosea sp. PAMC 26642 used in this study was isolated from the Arctic lichen Stereocaulon sp. There are 12 putative type II TA loci in the genome of Bosea sp. PAMC 26642. Of these, nine functional TA systems have been shown to be toxic in Escherichia coli. The toxin inhibits growth, but this inhibition is reversed when the cognate antitoxin genes are coexpressed, indicating that these putative TA loci were bona fide TA modules. Only the BoVapC1 (AXW83_01405) toxin, a homolog of $\mathrm{VapC}$, showed growth inhibition specific to low temperatures, which was recovered by the coexpression of BoVapB1 (AXW83_01400). Microscopic observation and growth monitoring revealed that the BoVapC1 toxin had bacteriostatic effects on the growth of $E$. coli and induced morphological changes. Quantitative real time polymerase chain reaction and northern blotting analyses showed that the BoVapC1 toxin had a ribonuclease activity on the initiator tRNA ${ }^{\mathrm{fMet}}$, implying that degradation of tRNA ${ }^{\text {fMet }}$ might trigger growth arrest in E. coli. Furthermore, the BoVapBC1 system was found to contribute to survival against prolonged exposure at $4^{\circ} \mathrm{C}$. This is the first study to identify the function of TA systems in cold adaptation.
\end{abstract}

Keywords: toxin-antitoxin system; VapBC; endoribonuclease; Bosea; extremophile

\section{INTRODUCTION}

Toxin-antitoxin systems (TA systems) are genetic modules composed of a toxin, which is engaged in the regulation of vital processes, and an antitoxin that blocks the activities of the toxin (Mruk and Kobayashi 2014; Kedzierska and Hayes 2016). TA systems are widespread in prokaryotes. The recent availability of large amounts of genome sequencing data and the development of sophisticated bioinformatics tools have revealed that this wide distribution is the result of horizontal gene transfer (Van Melderen and De Bast 2009; Fozo et al. 2010; Habib et al. 2018; Akarsu et al. 2019). A toxin and its antidote antitoxin genes are typically organized in a bi-cistronic operon and are transcriptionally coexpressed (Ogura and Hiraga 1983; Mruk and Kobayashi 2014). Under normal growth conditions, the coexpressed antitoxin inhibits the expression or activity of the

\footnotetext{
${ }^{3}$ These authors contributed equally to this work.

Corresponding author: hwangjh@pusan.ac.kr

Article is online at http://www.rnajournal.org/cgi/doi/10.1261/rna. 078786.121. Freely available online through the RNA Open Access option.
}

toxin. However, under stress conditions, labile antitoxins are degraded by RNases or proteases (Lon or Clp), releasing and activating the toxin (Roberts et al. 1994; Van Melderen et al. 1994; Lehnherr and Yarmolinsky 1995; Mikkelsen and Gerdes 1997; Brantl and Jahn 2015; Muller et al. 2016; Muthuramalingam et al. 2016).

Toxins are always proteins, whereas an antitoxin can be either a protein or a regulatory RNA (Short et al. 2018; Horesh et al. 2020). TA systems are classified into six types $(\mathrm{I}-\mathrm{VI})$ according to the biochemical nature of the antitoxin and the mechanism of regulation of the toxin by the antitoxin (Lobato-Marquez et al. 2016; Kang et al. 2018; Kato et al. 2019; Horesh et al. 2020). In types I and III, the antitoxins are noncoding RNAs that directly bind to toxin mRNAs (type I) or proteins (type III) (Gerdes et al. 1986; Fineran et al. 2009; Brantl and Jahn 2015). The antitoxins of types II and IV TA systems are proteins which directly interact with toxin proteins to inhibit the activity

(C) 2021 Jeon et al. This article, published in RNA, is available under a Creative Commons License (Attribution 4.0 International), as described at http://creativecommons.org/licenses/by/4.0/. 
of toxins (type II), or indirectly obstruct toxins by binding to the target of the toxin (type IV) (Tam and Kline 1989; Masuda et al. 2012). Type $V$ antitoxin has ribonuclease activity, and cleaves the mRNA of the toxin (Wang et al. 2012), while type $\mathrm{VI}$ antitoxin induces the degradation of a toxin by attracting the appropriate protease (Aakre et al. 2013).

Among the six types of TA systems, the type II TA system is ubiquitous in prokaryotic genomes (Leplae et al. 2011). Based on amino acid sequence similarity, toxins of the type II TA system can be further classified into nine superfamilies: RelE/ParE, MazF/CcdB, HicA, VapC, HipA, FicT/ Doc, AtaT/TacT, Zeta, and MbcT (Zhang et al. 2020). Many of the type II toxins are ribonucleases that cleave various targets of mRNAs, rRNAs, or tRNAs, thereby resulting in inhibition of translation (Kang et al. 2018). In a type II TA system, its expression is auto-regulated by the binding of the antitoxin to the promoter, repressing transcription (Black et al. 1994; de la Hoz et al. 2000; Afif et al. 2001; Santos-Sierra et al. 2002; Zhang et al. 2003; Smith and Magnuson 2004; Gerdes et al. 2005; Cataudella et al. 2012). The affinity of an antitoxin for its own promoter can be strengthened by forming a complex with the toxin (Magnuson and Yarmolinsky 1998; Afif et al. 2001; Li et al. 2008; Overgaard et al. 2008; Garcia-Pino et al. 2010). This regulation, therefore, is typically controlled by the stoichiometric ratio of toxins and antitoxins, and is called conditional cooperativity (Afif et al. 2001; Overgaard et al. 2008; Garcia-Pino et al. 2010; Boggild et al. 2012; Cataudella et al. 2012; Winther and Gerdes 2012).

The VapBC (virulence associated proteins) TA systems, consisting of toxin $\mathrm{VapC}$ and antitoxin $\mathrm{VapB}$, are the largest family of type II TA modules (Pullinger and Lax 1992; Pandey and Gerdes 2005; Sevin and Barloy-Hubler 2007). Multiple copies of vapBC loci are found in many prokaryotic genomes (Pandey and Gerdes 2005). For instance, the genomes of Mycobacterium tuberculosis and a thermophilic archaeon, Sulfolobus solfataricus encode 50 and 25 vapBC TA modules, respectively (Cooper et al. 2009; Ramage et al. 2009; Gupta et al. 2017). The VapC toxins belong to the PIN (PilT amino terminus) domain protein family, which shares structural similarity with the bacteriophage T4 RNase $H$, and shows ribonuclease activity (Arcus et al. 2011; Xu et al. 2016). With this ribonuclease domain, VapC toxins cleave primarily stable RNA species such as tRNA and rRNA in a sequence-specific manner (Winther and Gerdes 2011; Winther et al. 2013).

Bosea is a gram-negative bacterium belonging to the class $\alpha$-proteobacteria, family Bradyrhizobiaceae, which has been isolated from a range of environments such as soils, sediments, and hospital water (Das et al. 1996; La Scola et al. 2003). A unique feature of Bosea is its ability to oxidize thiosulfate (Das et al. 1996). Bosea sp. PAMC 26642, used in this study, was isolated from the Arctic lichen Streocaulon sp. (Kang et al. 2016). Bosea sp. PAMC
26642 has 12 type II TA systems, considerably more than Bosea species inhabiting warmer environments. Of note, among the eight Bosea species for which complete genome sequences are available, four do not have TA systems, Bosea vestrisii has two TA systems, Bosea caraganae has two, and Bosea psychrotolerans has five. Likewise, Mycobacterium tuberculosis, which is exposed to hypoxia, oxidative stress, limited nutrient, and low $\mathrm{pH}$, during macrophage infection (Wu et al. 2012), also has an enormous number of TA loci (approximately 90), whereas nonpathogenic mycobacteria possess relatively few TA loci (Ramage et al. 2009). Among them, PezT (Tandon et al. 2019), three MazFs (Tiwari et al. 2015), three RelEs (Singh et al. 2010), and six VapCs (Rengarajan et al. 2005; Agarwal et al. 2020; Sharma et al. 2020) toxins are critical for adaptation to various stresses such as oxidative stress, nutrient deprivation, drugs, or the internal macrophage environment.

We hypothesized that the abundance of type II TA systems in Bosea sp. PAMC 26642 may be related to adaptation of the bacterium to the cold environment of the Arctic. In this study, we identified 12 putative type II TA modules in the Bosea sp. PAMC 26642 genome, including five VapBC homologs, AXW83_01400-AXW83_01405, AXW83_069 15-AXW83_06920, AXW83_RS26480-AXW83_RS08500, AXW83_11460-AXW83_11465, and AXW83_12680-AXW 83_12685, using a web-based tool (Xie et al. 2018). The growth inhibition caused by these TAs was examined in Escherichia coli, and nine of the toxins were found to have an inhibitory effect on the growth of $E$. coli, which was neutralized by their cognate antitoxins. Among those nine TA systems, the expression of the BoVapC1 (AXW83_01405) toxin inhibited growth only at low temperatures by a bacteriostatic mechanism, and this growth inhibition was recovered by the coexpression of BoVapB1 (AXW83_01400). Furthermore, we demonstrated that BoVapC1 possesses cleavage activity against tRNA $A^{\text {fMet }}$ using quantitative real time polymerase chain reaction (qRT-PCR) and northern blotting, which may cause growth inhibition and increase survivability of E. coli at $4^{\circ} \mathrm{C}$.

\section{RESULTS}

\section{Evaluation of toxic effects of 12 type II TA modules in Bosea sp. PAMC 26642}

The 12 putative type II TA systems in the Bosea sp. PAMC 26642 genome were identified using TAfinder (Xie et al. 2018). They include five VapBCs (BoVapBC1; AXW83 01400-AXW83_01405, BoVapBC2; AXW83_06915-AXW 83_06920, BoVapBC3; AXW83_RS26480-AXW83_RS085 00, BoVapBC4; AXW83_11460-AXW83_11465, and Bo VapBC5; AXW83_12680-AXW83_12685), four HigBAs (BoHigBA1; AXW83_11315-AXW83_11320, BoHigBA2; AXW83_11955-AXW83_11960, BoHigBA3; AXW83_172 
95-AXW83_17300, and BoHigBA4; AXW83_18825-AX W83_18820), one RelBE (BoRelBE; AXW83_26140-AXW 83_26135), one HicAB (BoHicAB; AXW83_10240-AXW8 3_10245), and one FicAT (BoFicAT; AXW83_13170-AXW 83_13165) (Table 1; Fig. 1).

To investigate the functionality of these putative toxins, the growth-inhibitory effects of the toxins on E. coliwere assessed using spotting assays. Twelve toxin genes from Bosea sp. PAMC 26642 were cloned into PBAD33, which was transformed into the BL21(DE3) strain. All of the transformant colonies were scraped with M9 minimal media. They were diluted with the same media to an optical density at $600 \mathrm{~nm}\left(\mathrm{OD}_{600}\right)$ of 0.2 and serially diluted from $10^{-1}$ to $10^{-4}$. Each diluted bacterial suspension was spotted onto M9 agar plates with varying concentrations of arabinose, to determine the minimal concentration at which colony formation was inhibited by the expression of toxin. Eight of the 12 toxins produced a toxic effect on E. coli growth (BoVapC3, BoHicA, BoVapC4, BoHigB2, BoVapC5, BoHigB3, BoHigB4, and BoRelE) at both $37^{\circ} \mathrm{C}$ and $18^{\circ} \mathrm{C}$ (Fig. 2A; Supplemental Fig. S1). Transformants expressing BoHigB3 or BoHigB4 could not form colonies, even in the absence of arabinose. The toxic activity of BoVapC1 was temperature-dependent, being toxic only at $18^{\circ} \mathrm{C}$. In contrast, the remaining three putative toxins (BoVapC2, BoHigB1, and BoFicT) did not inhibit colony formation at either temperature. Toxicity of these predicted toxins were further assessed in $\alpha$-proteobacterium Rhodobacter sphaeroides 2.4.1. Expression of BovapC5 and BorelE inhibited the growth of $R$. sphaeroides at both $30^{\circ} \mathrm{C}$ and $15^{\circ} \mathrm{C}$, and BoVapC1 and BoVapC4 produced a toxic effect only at $15^{\circ} \mathrm{C}$ (Supplemental Fig. S2). These results indicate that BoVapC1 possesses the temperature-sensitive activity in both strains.

\section{Neutralization assay of nine TA modules}

To examine whether the cognate antitoxins could neutralize the activities of the toxins, nine cognate antitoxin genes were cloned into the pET21c vector. Prior to the neutralization assays, the inhibitory effects of the cognate antitoxins on cell growth were investigated. pET21c-antitoxin plasmids were transformed into BL21(DE3) cells, and the transformants were spotted on M9 agar plates containing

TABLE 1. Type II toxin-antitoxin systems in Bosea sp. PAMC 26642

\begin{tabular}{|c|c|c|c|c|}
\hline TA module (locus ${ }^{\mathrm{a}}$ ) & GenBank accession number & Length (aa) & Hits in $C D D^{b}$ & Toxicityc \\
\hline BoVapB1 (AXW83_01400) & AMJ63376.1 & 83 & MazE antitoxin & \\
\hline BoVapC1 (AXW83_01405) & AMJ59134.1 & 132 & PIN domain & + \\
\hline BoVapB2 (AXW83_06915) & AMJ60065.1 & 82 & - & \\
\hline BoVapC2 (AXW83_06920) & AMJ60066.1 & 137 & PIN domain & - \\
\hline BoVapB3 (AXW83_RS26480) & WP_156639880.1 & 78 & MazE antitoxin & \\
\hline BoVapC3 (AXW83_RS08500) & WP_066612303.1 & 133 & PIN domain & ++ \\
\hline BoHicA (AXW83_10240) & AMJ60619.1 & 64 & HicA toxin & + \\
\hline BoHicB (AXW83_10245) & AMJ60620.1 & 98 & HicB antitoxin & \\
\hline BoHigB1 (AXW83_11315) & Pseudogene & 88 & RelE/ParE_toxin & - \\
\hline BoHigA1 (AXW83_11320) & AMJ60803.1 & 100 & HTH_XRE domain & \\
\hline BoVapB4 (AXW83_11460) & AMJ60829.1 & 79 & StbC & \\
\hline BoVapC4 (AXW83_11465) & AMJ60830.1 & 139 & PIN domain & + \\
\hline BoHigB2 (AXW83_11955) & AMJ60913.1 & 98 & HigB toxin & + \\
\hline BoHigA2 (AXW83_11960) & AMJ63636.1 & 124 & HTH_XRE domain & \\
\hline BoVapB5 (AXW83_12680) & AMJ61033.1 & 71 & RHH_3 domain & \\
\hline BoVapC5 (AXW83_12685) & AMJ61034.1 & 121 & PIN domain & + \\
\hline BoFicA (AXW83_13170) & AMJ61116.1 & 165 & HTH_XRE domain & \\
\hline BoFicT (AXW83_13165) & AMJ61115.1 & 196 & Fic & - \\
\hline BoHigB3 (AXW83_17295) & AMJ61827.1 & 94 & RelE/ParE_toxin & +++ \\
\hline BoHigA3 (AXW83_17300) & AMJ61828.1 & 98 & HTH_XRE domain & \\
\hline BoHigB4 (AXW83_18825) & AMJ62077.1 & 101 & RelE/ParE_toxin & +++ \\
\hline BoHigA4 (AXW83_18820) & AMJ62076.1 & 96 & HTH_XRE domain & \\
\hline BoRelB (AXW83_26140) & AMJ63318.1 & 87 & RelB & \\
\hline BoRelE (AXW83_26135) & AMJ63317.1 & 93 & RelE/ParE_toxin & ++ \\
\hline
\end{tabular}




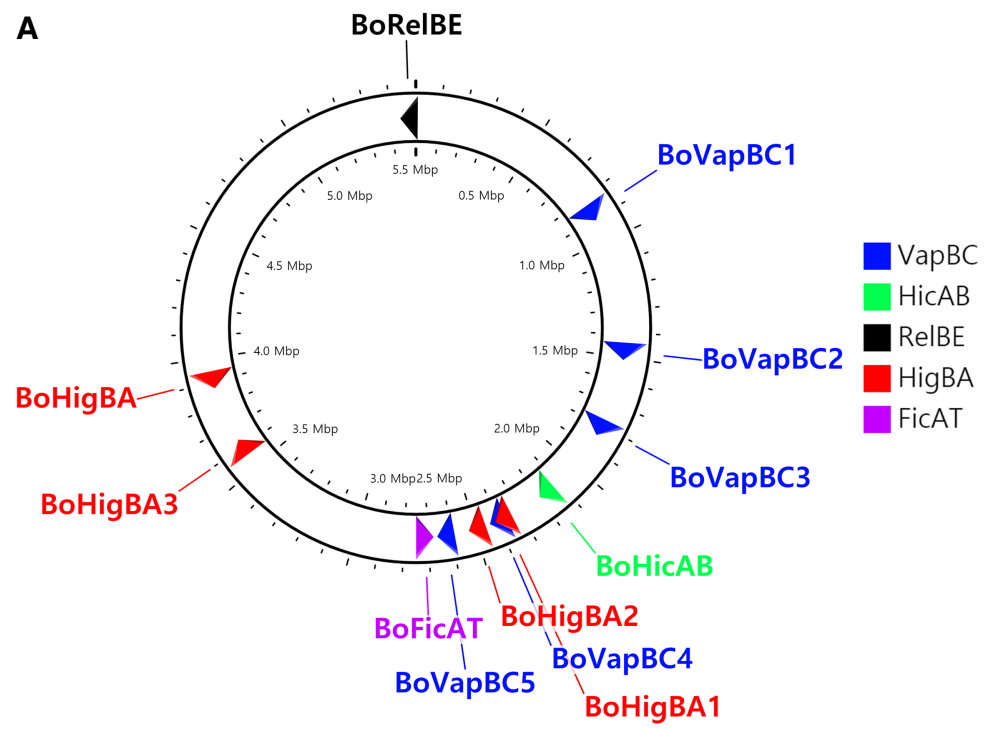

B
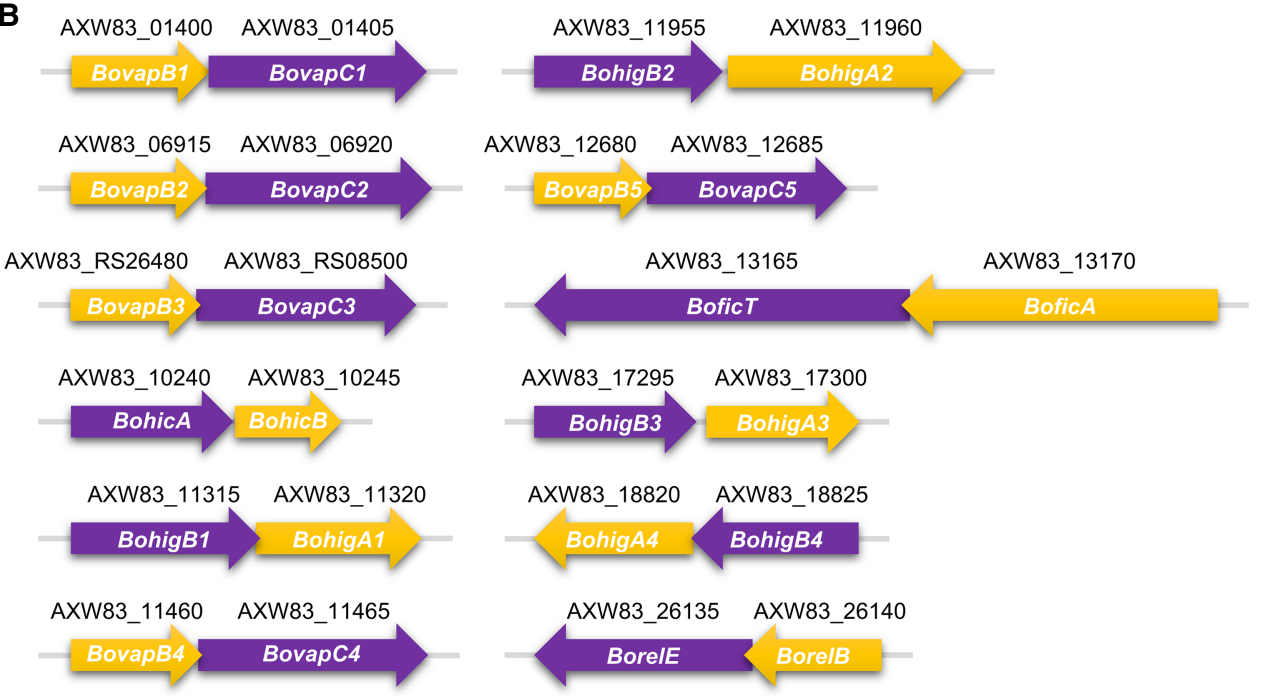

FIGURE 1. Type II TA modules of Bosea sp. PAMC 26642. (A) A schematic map of the Bosea sp. PAMC 26642 genome encoding 12 putative type II TA systems. A circular genome map was drawn using CG view (Stothard and Wishart 2005). (B) A schematic presentation of Bosea sp. PAMC 26642 type II TA genetic arrangements. The locus tags of the genes are shown above the arrows. Purple and yellow arrows indicate toxins and antitoxins, respectively.

various concentrations of isopropyl $\beta$-D-1-thiogalactopyranoside (IPTG). Expression of these antitoxins did not influence the growth of $E$. coli, except for BoHigA3 and BoRelB, which have marginal negative effects on colony formation at the highest concentration of IPTG $(0.1 \mathrm{mM})$ (Supplemental Fig. S3).

Next, to assess the ability of antitoxins to antagonize their cognate toxins, BL21(DE3) cells harboring pET21c or pET21c-antitoxin were transformed with pBAD33 or pBAD33-toxin and spotted on M9 agar plates with or without inducers. For the expression of toxins, different concentrations of arabinose were utilized as follows: BoVapC1; 0.1\%, BoHicA, BoVapC4, BoHigB2, and BoVapC5; 0.05\%, BoVapC3, BoHigB3, and BoRelE; 0.01\%, and
BoHigB $4 ; 0.005 \%$. The expression of the antitoxins was induced with 0.02 mM IPTG, except for BoHigA2, for which expression was induced with $0.1 \mathrm{mM}$ IPTG.

Consistent with previous results (Fig. 2A), the colony formation of double-transformed cells was affected by the induction of toxin in the presence of arabinose (Supplemental Fig. S4). In the presence of both arabinose and IPTG, BL21(DE3) cells with pET21c and pBAD33-toxin showed defects in colony formation ability, which was reversed by coexpression of the toxin and the antitoxin in the cells harboring pET21c-antitoxin and pBAD33-toxin (Fig. 2B). These results suggest that these antitoxins inactivated the function of their respective toxins, and that these nine TA systems appeared to be bona fide TA systems. 
A

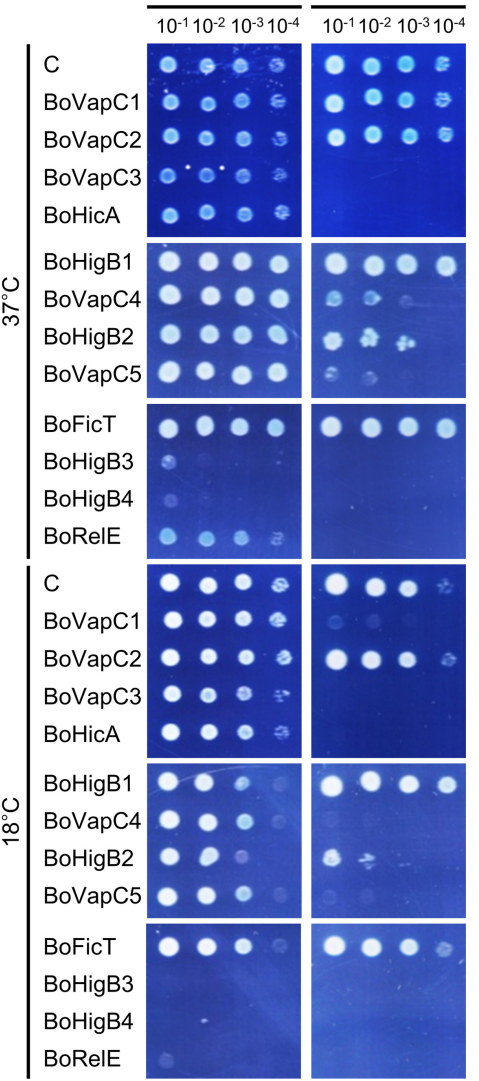

B

$\frac{\text { No inducer }}{10^{-1} 10^{-2} 10^{-3} 10^{-4}} \frac{\text { IPTG \& Ara }}{10^{-1} 10^{-2} 10^{-3} 10^{-4}}$

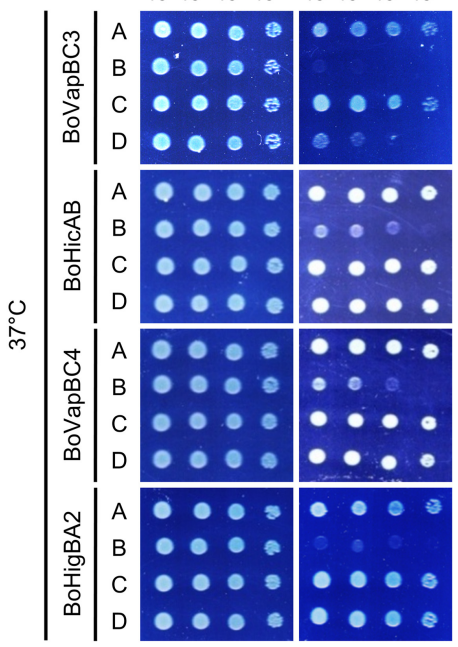

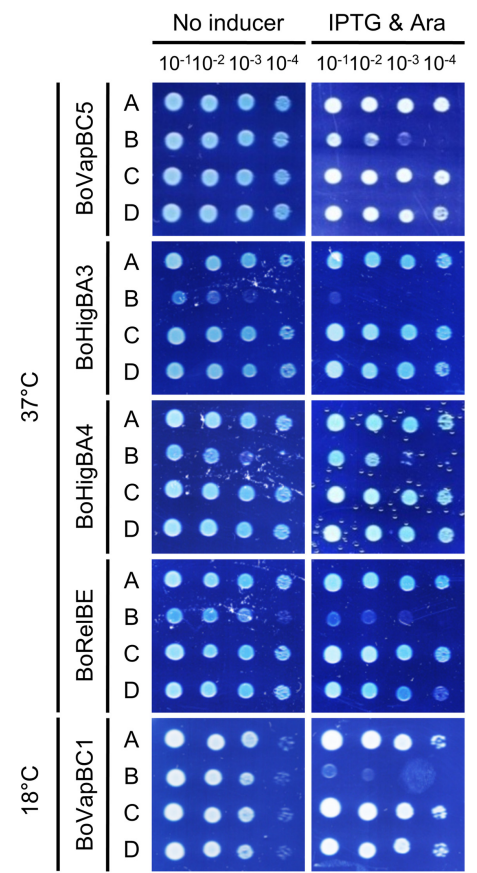

FIGURE 2. Phenotypes caused by toxins and their cognate antitoxins in E. coli. (A) The toxic effect of nine toxins of Bosea sp. PAMC 26642 on E. coli growth. E. coli BL21(DE3) cells transformed with PBAD33 or pBAD33-toxin were spotted on M9 agar plates supplemented with or without $0.1 \%$ arabinose, followed by incubation at $37^{\circ} \mathrm{C}$ or $18^{\circ} \mathrm{C}$. C indicates pBAD33. (B) Neutralization of toxin effects by antitoxin expression. E. coli $\mathrm{BL} 21(\mathrm{DE} 3)$ cells transformed with $\mathrm{pET} 21 \mathrm{c}$ or $\mathrm{pET} 21 \mathrm{c}$-antitoxin were spotted on $\mathrm{M} 9$ agar plate supplemented with or without both arabinose and IPTG, and the plates were incubated at $37^{\circ} \mathrm{C}$ or $18^{\circ} \mathrm{C}$. A; cells with pBAD33/pET21c, B; pBAD33-toxin/pET21c, C; pBAD33/pET21c-antitoxin, and D; pBAD33-toxin/pET21c-antitoxin.

\section{Characterization of the BoVapBC1 TA module}

Of the nine functional toxins, only BoVapC1 exhibited low-temperature-specific growth-inhibitory activity in both E. coli and R. sphaeroides, implying that BoVapC1 may play a more regulatable role in the adaptation of Bosea sp. PAMC 26642 to extreme or cold environments than other toxins. Therefore, our studies were focused on the BoVapBC1 TA module.

Using multiple sequence alignment, the amino acid sequences of BoVapB1 and BoVapC1 proteins were compared with other VapB or VapC homologs, respectively, in other bacteria such as Shigella flexneri, Sinorhizobium meliloti, Actinobacteria bacterium, and Bacteroides fragilis. As shown in Figure 3A, the toxin BoVapC1 had a high level of sequence similarity with other $\mathrm{VapC}$ homologs. BoVapC1 had 64\%, 57\%, 55\%, and 50\% amino acid identity with S. meliloti, A. bacterium, S. flexneri, and B. fragilis, respectively. The PIN domain in VapC harbors three to five conserved acidic amino residues, which form a negatively charged pocket for divalent metal cations and create the active site for metal-dependent ribonuclease activity (Senissar et al. 2017). These acidic residues were found to be well conserved in BoVapC1 (Fig. 3A). As shown in Figure 3B, the D7, E42, D98, or E119 residues in BoVapC1 were substituted with alanine to investigate whether the four conserved acidic residues in the active site are indispensable for its toxicity. Upon induction, the four mutants did not exhibit any growth-inhibitory activity in BL21(DE3). These results suggest that these four acidic amino acid residues play a pivotal role in the toxicity of BoVapC1, and that the growth inhibition was caused by the BoVapC1 protein.

To confirm that BoVapC1 inhibited cell growth in liquid media, BL21(DE3) cells harboring pBAD33 or pBAD33BoVapC1 were grown in $\mathrm{M} 9$ minimal media supplemented with chloramphenicol. Arabinose (0.4\%) was added for toxin expression during the early exponential phase. The growth was inhibited by BoVapC 1 expression at $18^{\circ} \mathrm{C}$ but was not inhibited at $37^{\circ} \mathrm{C}$ (Supplemental Fig. S5A,B). The expression of the antitoxin BoVapB1 induced by 0.1 mM IPTG had no effect on the growth of E. coli (Supplemental Fig. S5C). In 
A

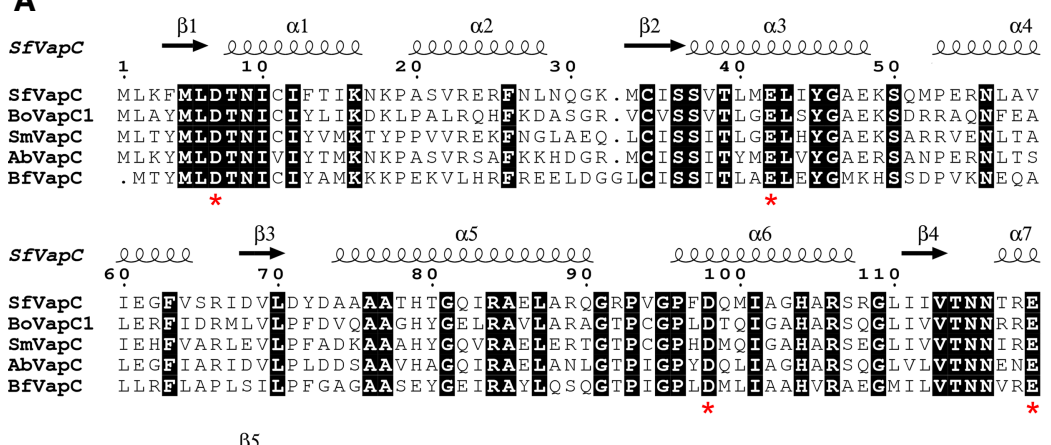

B

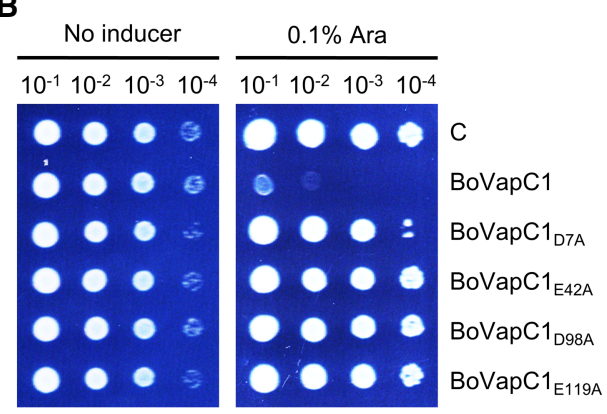

FIGURE 3. Multiple sequence alignment of BoVapC1 with previously characterized VapC homologs in other bacteria. (A) The primary sequence of BoVapC1 (AXW83_01405) was aligned with various VapC homologs in S. flexneri (Sf), S. meliloti (Sm), A. bacterium (Ab), and B. fragilis (Bf). The secondary structure of $\mathrm{SfVapC}$ is presented above the alignment. The acidic amino acid residues which are conserved in the active site of $V a p C$ are shown by red asterisks at the bottom of the alignment. The numbers correspond to the residues. The GenBank accession numbers for the VapC homologs are as follows: SfVapC; WP_000911329.1, SmVapC; WP_003527486.1, AbVapC; NDA60252.1, BfVapC; KAA4851476.1. (B) Effect of mutations in conserved acidic residues of BoVapC on growth-inhibitory activity. E. coli BL21(DE3) cells were transformed with pBAD33, pBAD33BoVapC1, or pBAD33-BoVapC1 mutants. The transformant colonies were scraped and diluted as described in Figure 2. Bacterial suspensions were spotted on $\mathrm{M} 9$ agar plates supplemented with $0 \%$ and $0.1 \%$ arabinose. The plates were incubated at $18^{\circ} \mathrm{C}$. C indicates pBAD33.

M9 minimal media supplemented with $0.4 \%$ arabinose and $0.1 \mathrm{mM}$ IPTG, the growth defect caused by the toxin BoVapC1 was recovered by coexpression with the antitoxin BoVapB1, indicating that BoVapB1 can antagonize the activity of BoVapC1 in vivo (Fig. 4A). By primary and tertiary structure comparisons with $S$. flexneri $\mathrm{VapBC}$, three aromatic amino acids (W53, F56, and F57) of BoVapB1 were predicted to interact tightly with the hydrophobic core of the VapC toxin (Supplemental Fig. S6; Dienemann et al. 2011), possibly leading to neutralization of BoVapC1. As shown in Figure $4 B$, the BoVapB1 mutants failed to antagonize the BoVapC1 toxicity, suggesting that neutralization by BoVapB1 expression in Figure 4A is unambiguously mediated by direct interactions between BoVapB1 and BoVapC1.

\section{BoVapC1-mediated cell elongation and its bacteriostatic effects}

Under stress conditions, free toxins released from antitoxins trigger either reversible cell growth arrest or programmed cell death (Hayes 2003). To determine whether the toxic effect of BoVapC1 was bacteriostatic or
A

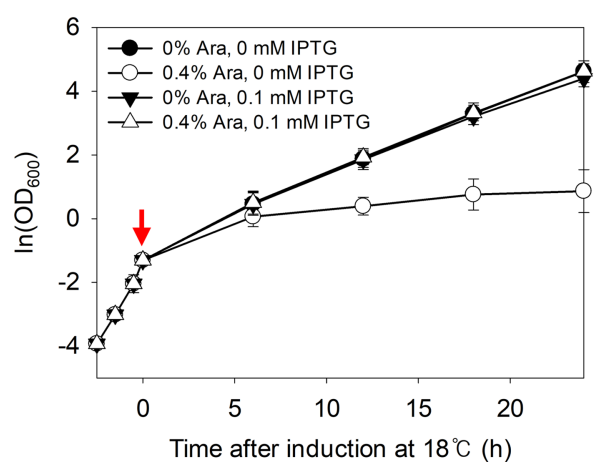

B

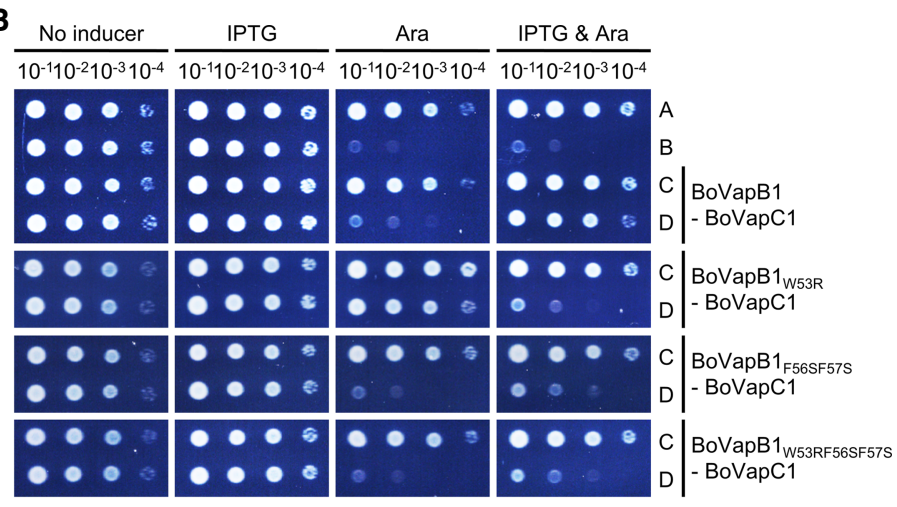

FIGURE 4. Growth inhibition by BoVapC1 and its recovery by BoVapB1. (A) Neutralization of BoVapC1-mediated growth inhibition by BoVapB1. BL21(DE3) cells harboring pET21c-BoVapB1 and pBAD33-BoVapC1 were cultivated as described in Materials and Methods, and OD 600 values were measured. Red arrow indicates induction starting point. (B) Neutralization of BoVapC1 by BoVapB1 mutants. The BL21(DE3) cells pretransformed with pET21c, pET21c-BoVapB1, or pET21c-BoVapB1 mutants were double transformed with pBAD33 or pBAD33-BoVapC1. The neutralization assay was conducted as described in Figure 2. A; cells with pBAD33/pET21c, B; pBAD33-BoVapC1/pET21c, C; pBAD33/pET21cBoVapB1, and D; pBAD33-BoVapC1/pET21c-BoVapB1. 
bactericidal, live/dead staining was conducted using cells expressing BoVapC1. BL21(DE3) cells harboring pBAD33 or pBAD33-BoVapC1 were cultured, and harvested after induction with arabinose, as described in the Materials and Methods. Propidium iodine (PI), which can penetrate only dead cells through the damaged membrane, and fluoresces red, was used to stain dead cells (Stocks 2004). For live cell staining, SYTO9, which is a membrane-intercalat- ing dye fluorescing green, was used (Stocks 2004). As shown in Figure 5A, upon induction by arabinose, both control and toxin-expressing cells were stained with SYTO9, but not with $\mathrm{Pl}$, indicating that most cells were alive. These findings were further confirmed using quantitative analysis to calculate the percentage of live cells, as described in the Materials and Methods. After the induction of BoVapC1 for $24 \mathrm{~h}$, nearly all cells were found to be

A pBAD33 pBAD33-BoVapC1

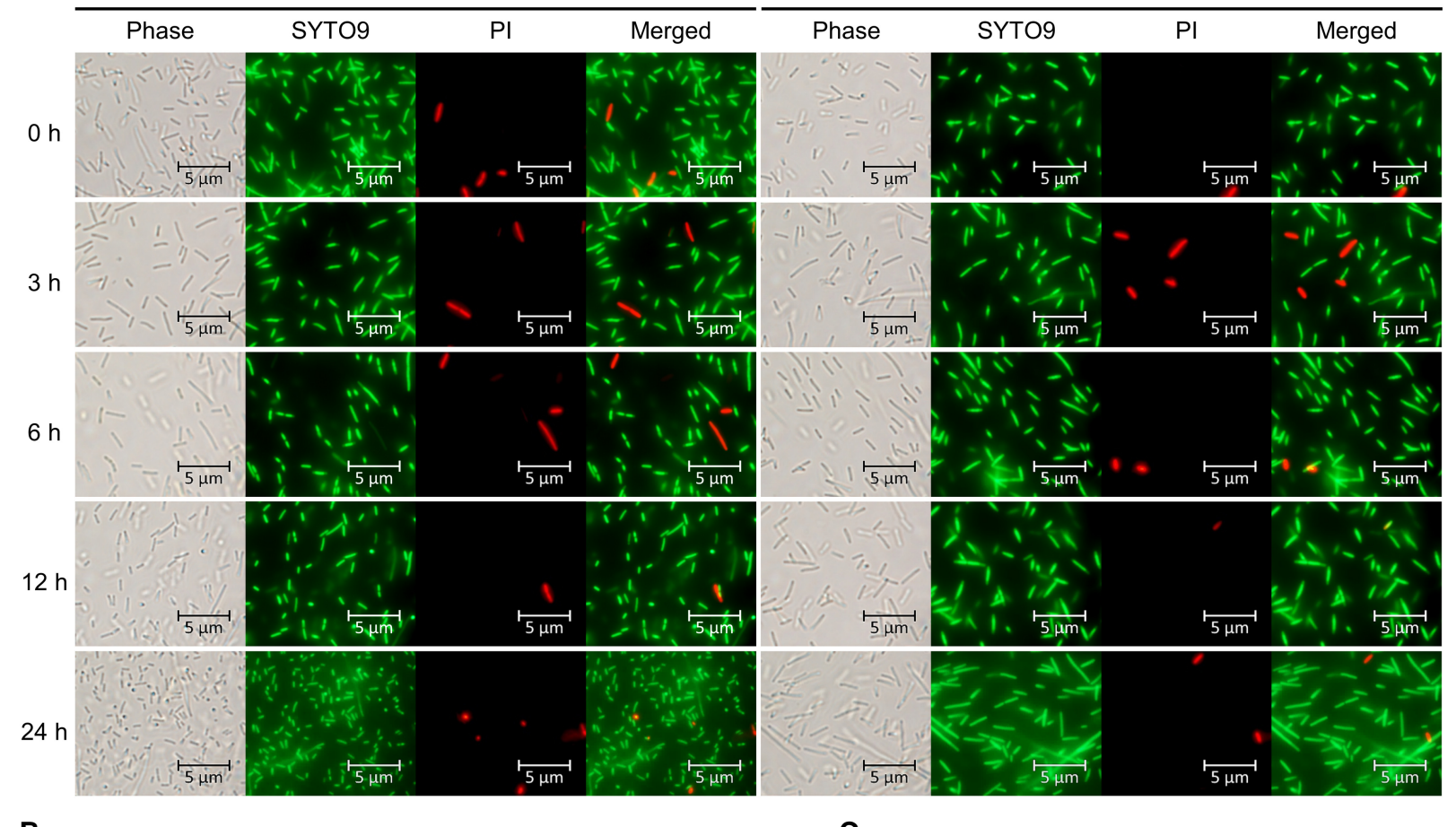

B
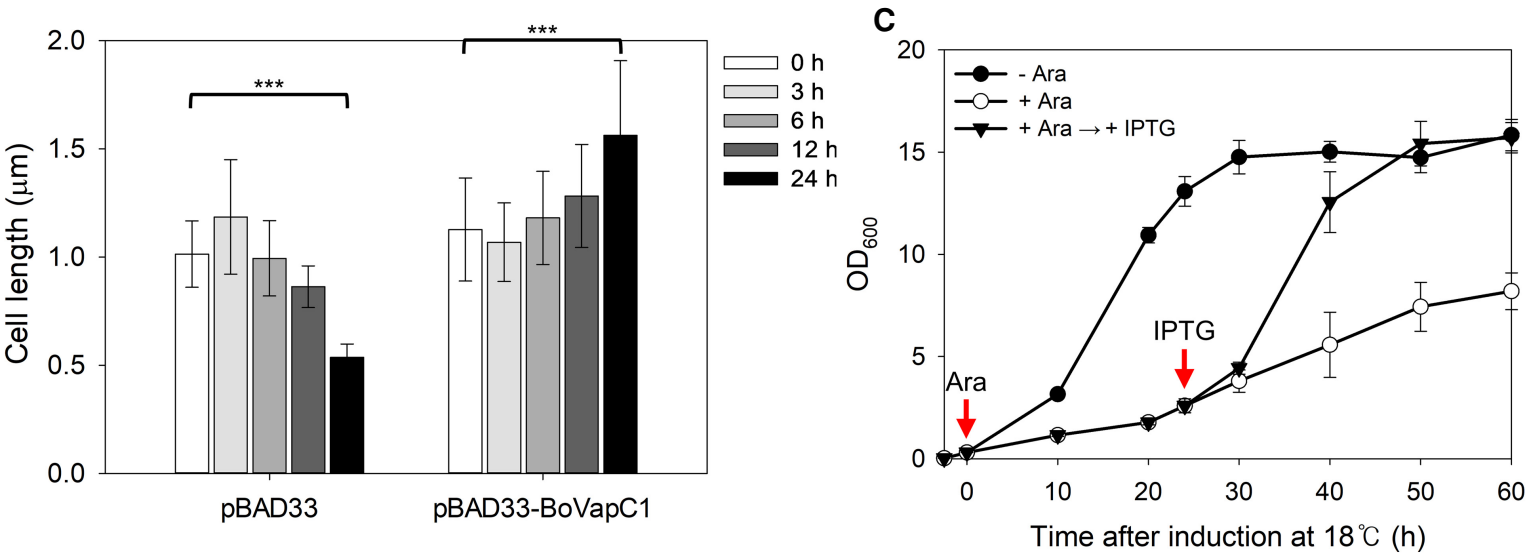

FIGURE 5. Bacteriostatic effect of BoVapC1 on E. coli growth. (A) Live/dead staining of BL21(DE3) cells expressing BoVapC1. E. coli BL21(DE3) transformants harboring pBAD33 or pBAD33-BoVapC1 were grown and stained for fluorescence microscopy as described in Materials and Methods. (B) Effect of BoVapC1 expression on the cell length of E. coli. Cell length data from Figure 5A was obtained using the Microbe J plugin for ImageJ (Ducret et al. 2016). One hundred and thirty seven cells were counted for each condition. Error bars represent SD. Statistical significance was derived using the two-tailed t-test. $\left(^{* * *}\right) P<0.001$. (C) Resumption of cell growth by antitoxin expression. BL21(DE3) cells harboring both pET21c-BoVapB1 and pBAD33-BoVapC1 were grown in M9 media containing Amp and $\mathrm{Cm}$ at $37^{\circ} \mathrm{C}$ to the early exponential phase. Then, the bacterial culture was diluted fivefold in fresh M9 media supplemented without (0) or with $0.4 \%$ arabinose, respectively, and further incubated at $18^{\circ} \mathrm{C}$ for $60 \mathrm{~h} \mathrm{(O).} \mathrm{At} 24 \mathrm{~h}$ after toxin induction, IPTG was added at a final concentration of $0.1 \mathrm{mM}(\boldsymbol{\nabla})$. Red arrows indicate induction starting points. Three independent experiments were carried out, and error bars represent SD. 
alive (Supplemental Fig. S7A). Of note, the control strain with pBAD33 exhibited reduced cell length after $24 \mathrm{~h}$ induction at $18^{\circ} \mathrm{C}$ (Fig. 5A,B), a finding which is consistent with that of a previous report showing shorter cells at lower temperature (Trueba et al. 1982). Conversely, upon the induction of BoVapC1, gradual elongation of cell length was observed (Fig. 5B). These findings suggest that although the growth-inhibitory effect of BoVapC1 blocked cell division, it was not lethal.

This bacteriostatic phenotype was further verified using cell growth resumption experiments. BL21(DE3) cells cotransformed with pBAD33-BoVapC1 and pET21cBoVapB1 were grown to the early exponential phase at $37^{\circ} \mathrm{C}$, then transferred to $18^{\circ} \mathrm{C}$. After the induction of BoVapC1 with arabinose for $24 \mathrm{~h}$ at $18^{\circ} \mathrm{C}$, cells were harvested and resuspended with M9 minimal medium containing $0.1 \mathrm{mM}$ IPTG, followed by further incubation at $18^{\circ} \mathrm{C}$ up to $60 \mathrm{~h}$. As shown in Figure $5 \mathrm{C}$, upon the induction of BoVapB1, growth resumed in the BoVapC1-expressing cells. This result was also confirmed by spotting assays as described previously ( $\mathrm{Li}$ et al. 2021). Cells expressing BoVapC 1 for $24 \mathrm{~h}$ at $18^{\circ} \mathrm{C}$ were revived in a noninducing plate (Supplemental Fig. S7B), suggesting that the effect of BoVapC1 is bacteriostatic rather than bactericidal.

\section{tRNA $^{\text {fMet }}$ cleavage activity of BoVapC1 in E. coli}

In various bacteria, VapC toxins inhibit protein synthesis through the hydrolytic cleavage of different RNAs, resulting in cell growth arrest (Ramage et al. 2009; Winther and Gerdes 2009). VapC homologs from S. flexneri, Salmonella enterica, nontypeable Haemophilus influenzae (NTHi), Leptospira interrogans, and a large number of VapCs from $M$. tuberculosis cleave tRNA site-specifically, between the anticodon stem and loop (Winther and Gerdes 2011; Lopes et al. 2014; Winther et al. 2016; Walling and Butler 2018). VapC20 and VapC26 from M. tuberculosis target and cleave the sarcin-ricin loop of $23 \mathrm{~S}$ rRNA (Winther et al. 2013, 2016). VapC homologs from M. smegmatis and $S$. solfataricus cleave mRNAs in a sequence-specific manner (Maezato et al. 2011; McKenzie et al. 2012). Therefore, to examine whether BoVapC1 also has RNA cleavage activity and to identify the RNA substrate(s) for BoVapC1, we conducted qRT-PCR. Total RNAs were extracted from BL21(DE3) cells harboring pBAD33 or pBAD33-BoVapC1 at $3 \mathrm{~h}$ after induction and CDNAs were then synthesized. qRT-PCR was performed using cDNAs and primer sets relevant to two rRNAs, including rrlA (23S rRNA) and rrsA (16S rRNA), five mRNAs of various sizes (polA; $\sim 3 \mathrm{~kb}$, glys; $\sim 2 \mathrm{~kb}$, gmd, hisG, and holA; $\sim 1 \mathrm{~kb}$ ), and three tRNAs (the sole histidine tRNA; hisR, the elongator methionine tRNA; metU, and the initiator methionine tRNA; metV) (Supplemental Table S1). As shown in Figure 6A, there was no significant change in the amounts of two rRNAs and these five
mRNAs. In contrast, the transcript level of metV decreased 1.63-fold by BoVapC1 expression, while that of metU increased by 1.25 -fold, and that of hisR was not affected in BoVapC1-expressing cells (Fig. 6A). To further verify the tRNA ${ }^{\text {fMet }}$-specific cleavage activity of BoVapC1, northern blotting was carried out using RNAs extracted from BL21 (DE3) cells harboring pBAD33 or pBAD33-BoVapC1 at 0 $\mathrm{h}$ and $3 \mathrm{~h}$ after induction. The full-length tRNA ${ }^{\text {fMet }}(77 \mathrm{nt})$ was observed intact in BL21(DE3) cells carrying pBAD33 regardless of induction (Fig. 6B, left two lanes, right panel). In contrast, after BoVapC1 induction, cleaved tRNA ${ }^{\text {fMet }}$ $(<50 \mathrm{nt})$, which was not detected before induction, appeared with a concomitant reduction of full-length tRNA ${ }^{\text {fMet }}$ (Fig. 6B, right two lanes, right panel). The elongator tRNAs, tRNA ${ }^{\text {His }}$ and tRNA ${ }^{\text {Met }}$, remained constant without any degradation even after BoVapC1 overexpression (Fig. 6B, left and middle panels). Consistent with colony formation phenotype, no notable change was observed in those RNAs at $37^{\circ} \mathrm{C}$ (Supplemental Fig. S8). These results suggest that BoVapC 1 specifically cleaves the initiator tRNA ${ }^{\text {fMet }}$ only at low temperatures with a site-specific endoribonuclease activity. The decline in the level of tRNA $^{\text {fMet }}$ caused by BoVapC1 expression was neutralized by the expression of BoVapB1 antitoxin (Fig. 6C). The increased level of metU in BoVapC1-expressing cells also reverted to the normal level by coexpression of BoVapB1. No significant change was noted in the level of hisR by the expression of BoVapB1, BoVapC1, or both proteins.

These results led us to examine whether the overexpression of metZWV operon encoding tRNA ${ }^{\mathrm{fMet}}$ could attenuate the BoVapC1-mediated growth inhibition at $18^{\circ} \mathrm{C}$. Thus, we cloned metZWV operon into the pBR322 vector. BL21(DE3) cells harboring plasmid pairs (pBAD33/ pBR322, pBAD33-BoVapC1/pBR322, pBAD33/pBR322metZWV, or pBAD33-BoVapC1/pBR322-metZWV) were prepared and spotted on M9 agar plates with or without $0.1 \%$ arabinose. As shown in Figure $6 \mathrm{D}$, overexpression of metZWV partially restored the growth defect caused by BoVapC overexpression at $18^{\circ} \mathrm{C}$.

Our results indicate that initiator $\mathrm{tRNA} \mathrm{A}^{\mathrm{fMet}}$ of $E$. coli can serve as a substrate for the toxin $\mathrm{BoVapC} 1$ at $18^{\circ} \mathrm{C}$, which causes inhibition of translation, and subsequently growth arrest, and that BoVapB1 neutralized BoVapC1 by inhibiting the ribonuclease activity of $\mathrm{BoVapC} 1$, resulting in growth resumption. Furthermore, given the high sequence identity between E. coli and Bosea sp. PAMC 26642 tRNA $^{\mathrm{fMet}}$ s (Fig. 6E), BoVapC1 likely controls cell growth of Bosea sp. PAMC 26642 at low temperature using the same mechanism.

\section{Contribution of BoVapBC1 to cold tolerance}

As mentioned earlier, TA systems were found to be lacking in other Bosea species occurring in a comparatively mild temperature environment (Supplemental Table S3). Of 
A

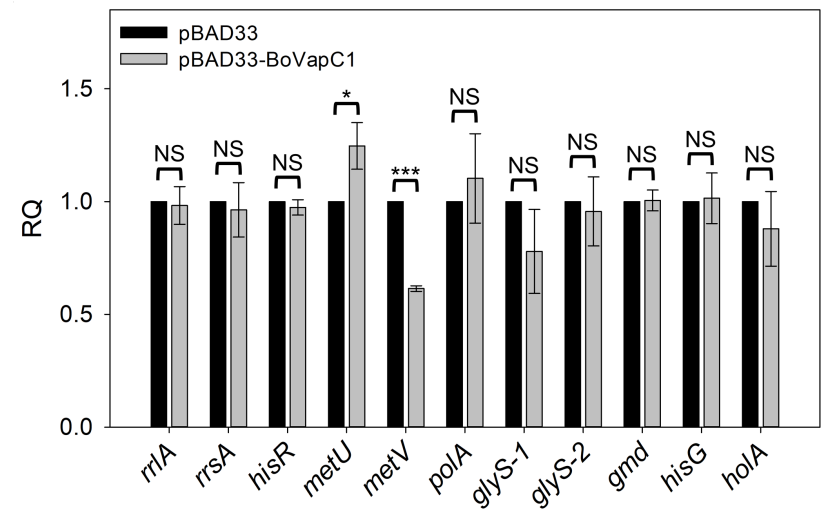

B

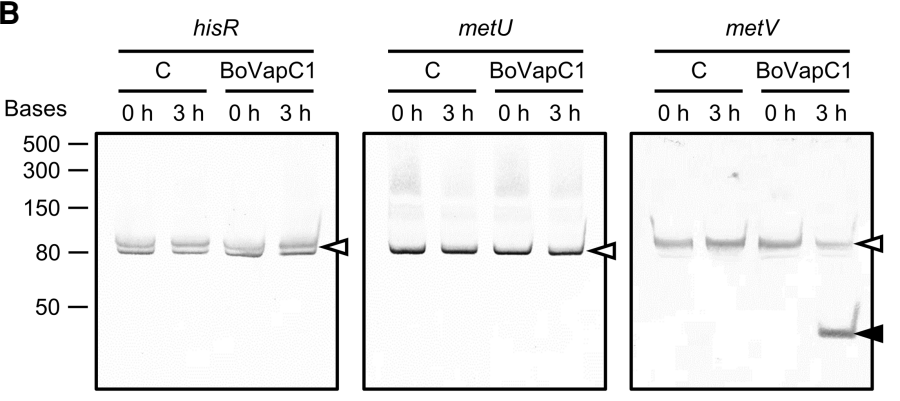

C

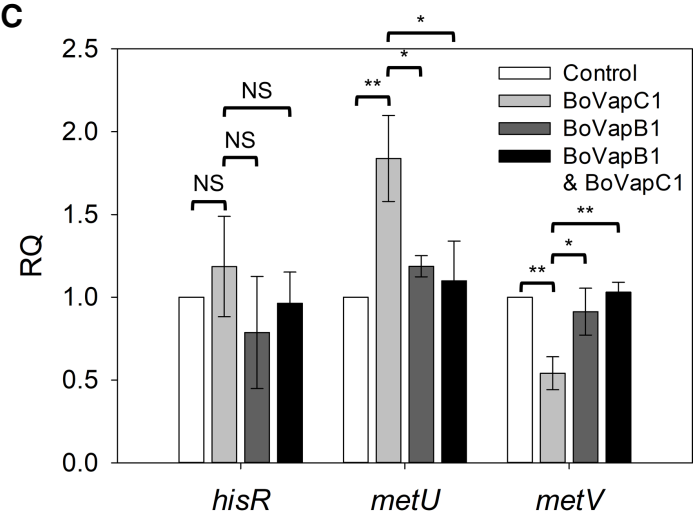

D $\quad \frac{\text { No inducer }}{10^{-1} 10^{-2} 10^{-3} 10^{-4}} \frac{0.1 \% \text { Ara }}{10^{-1} 10^{-2} 10^{-3} 10^{-4}}$

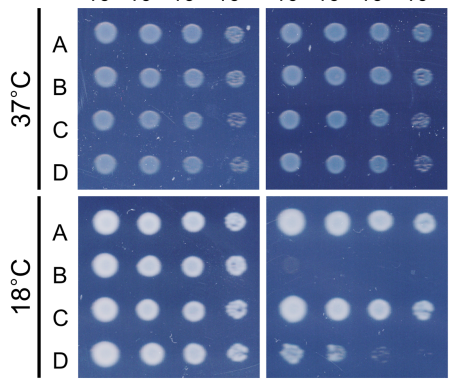

E

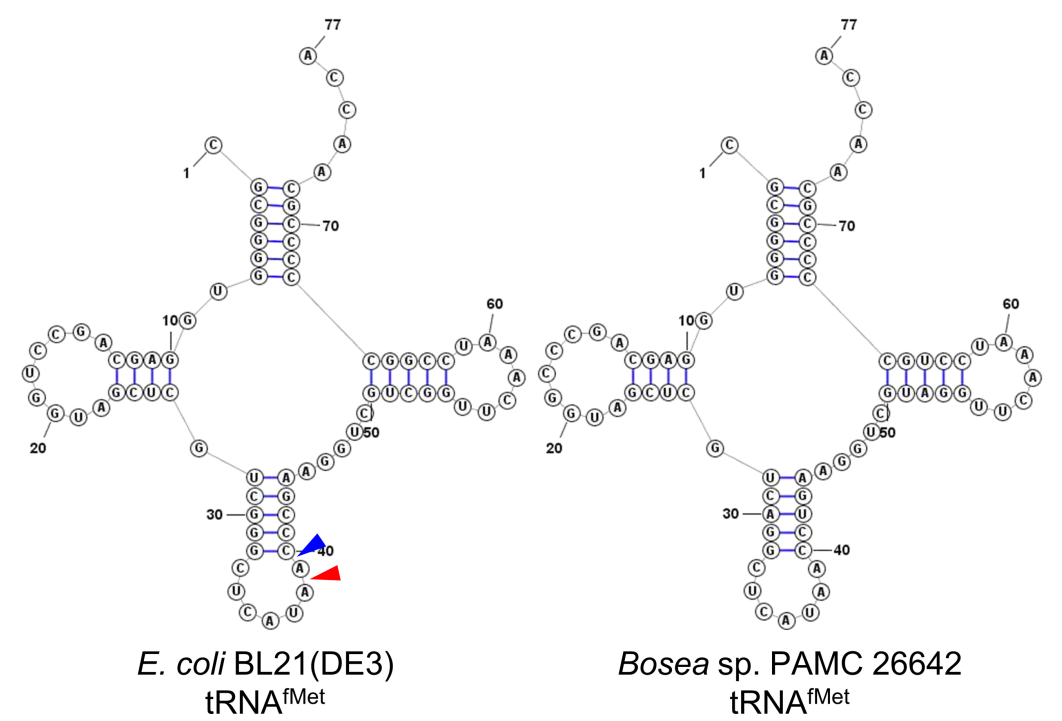

FIGURE 6. $t R N A^{\text {fMet }}$-specific cleavage activity of BoVapC1. (A) qRT-PCR analyses of the level of mRNAs, rRNAs, and tRNAs. BL21(DE3) cells harboring pBAD33 or pBAD33-BoVapC1 were cultivated as described in Materials and Methods. Total RNAs extracted from these cells were utilized for qRT-PCR analyses. Experiments were independently conducted three times, and error bars represent SD. NS, nonsignificant; $\left({ }^{*}\right) P<0.05 ;\left({ }^{* * *}\right)$ $P<0.001$. (B) Northern blotting analyses of tRNAs. RNAs were extracted from BL21(DE3) cells carrying pBAD33 (C) or pBAD33-BoVapC1 (BoVapC1) before $(\mathrm{O} h$ ) and after induction $(3 \mathrm{~h})$ and blotted with biotin-labeled oligonucleotides which are specific to the tRNAs as described in Materials and Methods. Full-length or cleaved tRNAs are indicated with open or filled arrowheads, respectively. Low Range ssRNA Ladder (New England Biolabs) was used as a size marker. (C) Inhibition of BoVapC1 ribonuclease activity by BoVapB1. BL21(DE3) cells harboring plasmid pairs were cultivated as described in Materials and Methods. Total RNAs extracted from these cells were utilized for qRT-PCR analyses. Experiments were independently performed three times. Error bars represent SD. NS, nonsignificant; $\left({ }^{*}\right) P<0.05 ;\left(^{* *}\right) P<0.01$. (D) Growth restoration by overexpression of metZWV in BoVapC1-expressing cell. The BL21(DE3) cells pretransformed with pBAD33 or pBAD33-BoVapC1 were double transformed with pBR322 or pBR322-metZWV. The spotting assay was conducted as described in Figure 2. A; cells with pBAD33/pBR322, B; pBAD33-BoVapC1/pBR322, C; pBAD33/pBR322-metZWV, and D; pBAD33-BoVapC1/pBR322-metZWV. (E) The sequences and secondary structures of tRNA ${ }^{\mathrm{fMet}} \mathrm{s}$. The structures of tRNA ${ }^{\mathrm{fMet}}$ of E. coli BL21(DE3) and Bosea sp. PAMC 26642 were drawn using StructureEditor (Reuter and Mathews 2010). Blue and red arrows indicate the positions cleaved by S. flexneri VapC (Winther and Gerdes 2011) and NTHi VapC (Walling and Butler 2018), respectively. 
the eight Bosea species with whole genome sequence available, four do not have TA systems, and $B$. vestrisii and $B$. caraganae have two TA loci each. Interestingly, $B$. psychrotolerans, a psychrotrophic bacterium that can grow at $5^{\circ} \mathrm{C}$ (Albert et al. 2019), has five TA modules, suggesting that TA systems in Bosea sp. PAMC 26642 are important for its cold tolerance. Therefore, to investigate whether the BoVapBC1 showing low temperature-specific activity is involved in cold tolerance, we compared the survival rates of $B L 21(D E 3)$ cells with pBAD33/pET21cBoVapB1 or pBAD33-BoVapC1/pET21c-BoVapB1. After induction with $0.4 \%$ arabinose for $3 \mathrm{~h}$ at $18^{\circ} \mathrm{C}$, the cultures were moved to refrigeration temperature $\left(4^{\circ} \mathrm{C}\right)$, followed by static incubation for a further $48 \mathrm{~h}$. The cells were harvested at 12-h intervals and the survival rates were analyzed as described in Materials and Methods. As the exposure time increased, the survival rates of cells harboring pBAD33 gradually reduced and reached $48.51 \%$ at 48 h (Fig. 7). The minimum survival rate of BoVapC1-expressing cells was $63.43 \%$ at 36 h; nevertheless, the survivability was higher than that of the control strain throughout the incubation. This finding suggests that BoVapBC1 enhanced the survivability of $\mathrm{E}$. coli at $4^{\circ} \mathrm{C}$ and further implies that it plays an important role in cold tolerance of Bosea sp. PAMC 26642.

\section{DISCUSSION}

In this study, we found 12 putative type II TA systems in Bosea sp. PAMC 26642 isolated from Arctic lichens. Five vapBC loci, four higBA loci, one relBE locus, one hic $A B$ locus, and one ficAT locus are encoded in the genome of

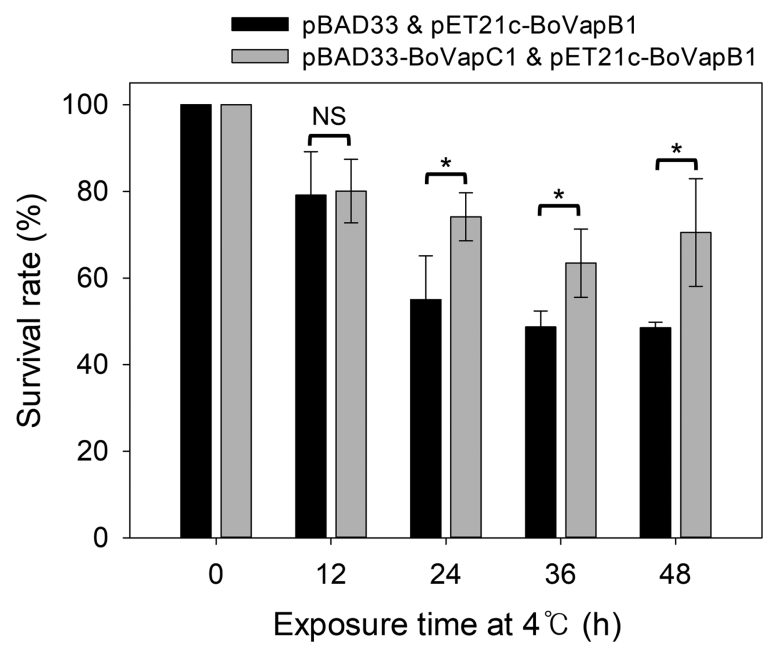

FIGURE 7. Survival rates of cells expressing BoVapC1 after exposure to $4^{\circ} \mathrm{C}$. The survival rates were obtained by calculating the percentage of the number of CFU in the BoVapC1-induced cells, compared with those in control cells. Experiments were performed in three independent repetitions and error bars represent SD. Statistical significance was derived from the two-tailed t-test. NS, nonsignificant; $\left(^{*}\right) P<0.05$.
Bosea sp. PAMC 26642 (Fig. 1). Of the 12 predicted toxins, nine toxins were found to have toxic effects on the growth of $E$. coli, which were recovered by coexpression of their cognate antitoxins (Fig. 2). Our studies focused on the BoVapBC1 (AXW83_01400-AXW83_01405) TA module because BoVapC1, which has a high sequence similarity to other VapCs (Fig. 3A), was the only toxin among the nine functional toxins whose growth-inhibitory activity was inducible by low temperatures (Fig. 2).

Even though many $\mathrm{VapC}$ family toxins target tRNA, rRNA, or mRNA, most of them are reported to cleave tRNAs. Of the thirteen VapC toxins in M. tuberculosis, eleven VapCs target elongator tRNAs, and the remaining two VapCs, VapC20 and VapC26, cleave 23S rRNA (Winther et al. 2013, 2016; Cruz et al. 2015). In addition, VapC homologs in S. enterica, S. flexneri, L. interrogans, and NTHi specifically cleave tRNA ${ }^{f M e t}$ in a sequence-specific and stemloop structure-specific manner (Winther and Gerdes 2011; Lopes et al. 2014; Walling and Butler 2018). However, VapC homologs of these four mesophilic bacteria have not been explored for temperature-dependent functionality in E. coli. Nevertheless, these VapC homologs of S. enterica, S. flexneri, and NTHi have been implicated in bacteriostatic dormancy (Winther and Gerdes 2011; Ren et al. 2012), like we have shown that BoVapC1 induction had a bacteriostatic effect on $E$. coli growth with elongated morphologies (Fig. 5). Similarly, in the view of tRNA inactivation, acetylation of tRNA by TacT and phosphorylation of glutamyl-tRNA-synthetase by HipA caused disturbances in translation initiation or elongation and ultimately arrested cell growth or division rather than cell death (Korch and Hill 2006; Helaine et al. 2014; Cheverton et al. 2016; Rycroft et al. 2018; Walling and Butler 2019).

Our qRT-PCR and northern blotting analyses indicated that the levels of the full-length tRNA ${ }^{\text {fMet }}$ were significantly reduced by the expression of BoVapC1 in E. coli only at low temperature (Fig. 6). In E. coli, initiator tRNA ${ }^{\text {fMet }} \mathrm{s}$ are produced from the metZWV and metY-nusA-infB operons (Ishii et al. 1984; Kenri et al. 1994). The metZWV operon contributes to $\sim 75 \%$ of the total intracellular tRNA ${ }^{\text {fMet, }}$, and the remaining were produced from met $Y$ (Kenri et al. 1994). The deletion or reduced expression of metZWV conferred a cold-sensitive phenotype, which was not present in metY deletion, suggesting that the total cellular level of $\mathrm{tRNA}^{\mathrm{fMet}}$ is crucial for growth at low temperature (Kapoor et al. 2011). After cold shock, the expression of met $Y$ as well as infB encoding translation initiation factor 2 (IF2) are induced from the metY-nusA-infB operon (Brandi et al. 2019). The levels of the other two translation initiation factors, IF1 and IF3, are also increased upon temperature downshift (Giangrossi et al. 2007; Giuliodori et al. 2007), indicating that translation initiation is critical for adjustment to cold growth conditions. The tRNA fMet $^{\text {of Bosea }}$ sp. PAMC 26642 has $94 \%$ nucleotide sequence identity with that of E. coli. Particularly, the anticodon stem-loop 
region, which is the target site of the VapC homologs (Winther and Gerdes 2011; Lopes et al. 2014), of Bosea sp. PAMC 26642 tRNA ${ }^{\text {fMet }}$ is identical to that of E. coli BL21(DE3) (Fig. 6E), suggesting that BoVapC1 is likely to cleave the tRNA ${ }^{\text {fMet }}$ in the Bosea sp. PAMC 26642 cells through the same cleavage mechanism. Unlike E. coli, Bosea sp. PAMC 26642 encodes only a single copy of the initiator $\mathrm{RRNA}^{\mathrm{fMet}}$ gene in its genome. Therefore, it is likely that BoVapC1 expression in Bosea sp. PAMC 26642 effectively triggers the reduction in the level of $\operatorname{tRNA}^{\mathrm{fMet}}$, which inhibits the formation of the translation initiation complex, consequently leading to the growth arrest at low temperature.

Taking the results of this study into account, the increased toxicity observed at $18^{\circ} \mathrm{C}$ compared with $37^{\circ} \mathrm{C}$, is possibly associated with an increased need for a tRNA ${ }^{\text {fMet }}$ target at a temperature that is this low; however, why tRNA ${ }^{\mathrm{fMet}}$ was cleaved by BoVapC1 only at $18^{\circ} \mathrm{C}$ (Fig. 6; Supplemental Fig. S8) is still unclear. Several type II toxins have been reported to be functionally affected by temperature, in the same manner as BoVapC1. In Pseudomonas putida, deletion of the gra $A$ antitoxin gene causes a reduction in the colony formation rate, which becomes apparent at low temperatures (Tamman et al. 2014). This reduction was caused by the decreased activity of GraT at $37^{\circ} \mathrm{C}$, not by the low expression level of graA (Tamman et al. 2014). In the case of the E. coli YafQ/DinJ TA system, either the deletion of the dinJ antitoxin gene or the overexpression of YafQ in the yafQ/dinJ operon-deleted cell leads to significant reduction in cell metabolism and proliferation at lower temperatures (Zhao et al. 2016). The lytic phenotype generated by the overexpression of another $E$. coli toxin, EzeT, becomes more pronounced at temperatures below $30^{\circ} \mathrm{C}$ (Rocker and Meinhart 2015). Another zeta toxin, Ld_ל1 domain of Leishmania donovani, also showed pronounced growth-inhibitory activity at lower temperatures (Srivastava et al. 2019).

Considering the temperature-sensitive phenotypes observed in our study and several other TA systems, we can propose three hypotheses to explain why BoVapC1 was active only at $18^{\circ} \mathrm{C}$ as follows: (i) BoVapC1 may aim to the target(s) such as tRNA ${ }^{\text {fMet }}$ that plays an important role during cold adaptation, (ii) the activity of BoVapC1 may be controlled by conformational changes induced by temperature, or (iii) there may be another regulator protein inactivating $\mathrm{BoVapC} 1$ at $37^{\circ} \mathrm{C}$ or activating it at $18^{\circ} \mathrm{C}$.

Cold-adapted proteins of psychrophilic bacteria have evolved to increase structural flexibility as well as stability at low temperature, whereas they show low thermal stability and heat labile-activity at higher temperatures (Feller 2013; Bruno et al. 2019). Therefore, as shown in Supplemental Figure S8, it is likely that the stability and/ or activity of $\mathrm{BoVapC1}$ diminishes at $37^{\circ} \mathrm{C}$ with no tRNA ${ }^{\mathrm{fMet}}$ cleavage activity, and that the conformation at $18^{\circ} \mathrm{C}$ gains access and catalytic activity to the substrate.
Nevertheless, the absence of BoVapC1 activity at $37^{\circ} \mathrm{C}$ does not appear to be a result of either reduced expression or instability of the BovapC1 mRNAs owing to the fact that a higher transcript level of BovapC1 was noted at $37^{\circ} \mathrm{C}$ compared with that at $18^{\circ} \mathrm{C}$ (Supplemental Fig. S9). Furthermore, we cannot rule out the possibility that a trans- or cross-regulator may modulate the function of BoVapC1 at either temperature (Yang et al. 2010; Zhu et al. 2010; Otsuka and Yonesaki 2012).

Interestingly, TA systems are more abundant in bacteria living in stressful environments compared with those living in constant environments, implying that TA modules function as cellular stress-response elements (Pandey and Gerdes 2005). Recent studies have demonstrated that the VapBC module, which is the most abundant TA subfamily in type II (Arcus et al. 2011), is indeed associated with adaptation to environmental stress through persister cell and biofilm formation (Ren et al. 2012; Levin-Reisman et al. 2017; Eroshenko et al. 2020). The VapBC-1 in NTHi contributes to survival capability under nutrient deficient condition or during infection process (Cline et al. 2012; Ren et al. 2012). VapC4, VapC20, VapC22, VapC26, and VapC45 of M. tuberculosis VapBC modules are associated with enhanced survival in macrophages or against oxidative stress (Rengarajan et al. 2005; Agarwal et al. 2020). In addition, the heat-shock inducible VapBC system of $\mathrm{S}$. solfataricus increases viability under thermal stress conditions (Cooper et al. 2009; Maezato et al. 2011). Nevertheless, the functional relationship between survival under cold stress conditions and $\mathrm{VapBC}$ system has not been elucidated yet. Therefore, even though our findings are based on experiments carried out in E. coli, it is of a great interest how, compared to other Bosea species in a mild habitat, Bosea sp. PAMC 26642 has evolved this system to endure the extremely low temperatures in the Arctic.

In this study, we identified nine functional type II TA systems in the Bosea sp. PAMC 26642 and characterized the possible function of the BoVapBC1 system at low temperature. BoVapC1, which cleaved tRNA ${ }^{f M e t}$ in a low temperature-dependent manner, enhanced the survivability of $E$. coli after being exposed to refrigeration temperature (Fig. 7). Presumably, this is the first study to identify temperature-dependent VapC toxin; however, further in vivo and structural studies are required to understand the role and mechanism of the BoVapBC TA system in the adaptation to environment in this extremophile.

\section{MATERIALS AND METHODS}

\section{Bacterial strains, media, and growth conditions}

The E. coli $\mathrm{BL} 21(\mathrm{DE} 3)$ strain was grown at $37^{\circ} \mathrm{C}$ or $18^{\circ} \mathrm{C}$ in LuriaBertani (LB) or M9 minimal media supplemented with $0.2 \%$ casamino acids and $0.4 \%$ glucose. When necessary, antibiotics were 
added at the following concentrations: ampicillin (Amp); 100 $\mu \mathrm{g} / \mathrm{mL}$ and chloramphenicol $(\mathrm{Cm}) ; 50 \mu \mathrm{g} / \mathrm{mL}$.

\section{Plasmid construction}

Twelve putative type II toxin and antitoxin genes in Bosea sp. PAMC 26642 were identified using TAfinder (https://bioinfo$\mathrm{mml} . s j t u . e d u . c n / T A f i n d e r / T A f i n d e r . p h p)$, and the open reading frames of those toxins were synthesized and cloned in pUCIDT (Cosmogenetech), yielding pUCIDT-toxin plasmids (Supplemental Table S2). The pUCIDT-toxin plasmids were digested by the appropriate restriction enzymes. The digested DNA fragments carrying toxin genes were cloned into the Ndel-Hindlll or NdelSacl sites of the pBAD33 vector containing arabinose-inducible araBAD promoter, and we used LB medium supplemented with $0.2 \%$ glucose to strongly repress the promoter (Guzman et al. 1995). Nine antitoxin genes were also synthesized and cloned into the Ndel-Hindlll sites of the pET21c vector containing $\beta$-D1-thiogalactopyranoside (IPTG)-inducible T7 promoter, yielding pET21c-antitoxin plasmids.

Point mutations were introduced into BoVapB1 or BoVapC1 by site-directed mutagenesis PCR using PUCIDT-BoVapB1 or pET21c-BoVapC1 as templates, respectively, and the primer sets listed in Supplemental Table S1. The toxin DNA fragments carrying each mutation were ligated into PBAD33, yielding $p B A D 33-B o V a p C 1_{D 7 A}, p B A D 33-B o V a p C 1_{E 42 A}, p B A D$ 33-BoVapC1 $1_{D 98 A}$, and PBAD33-BoVapC1 $1_{E 119 A}$. The mutated BoVapB1 DNA fragments were ligated into pET21c, yielding

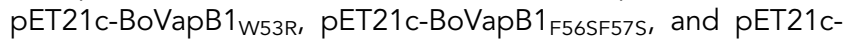

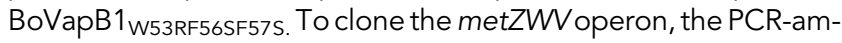
plified DNA fragments were ligated with the Smal site of pBR322, yielding pBR322-metZWV. All plasmids and primers used in this study are listed in Supplemental Tables S1, S2.

\section{In vivo toxin-antitoxin neutralization test}

To determine the minimal concentration of arabinose for the neutralization assay, BL21(DE3) cells were transformed with pBAD33 or pBAD33-toxin and plated on M9 agar plates containing $\mathrm{Cm}$, followed by incubation at $37^{\circ} \mathrm{C}$ overnight. Then, each transformant was scraped from the agar plates, and resuspended into $5 \mathrm{~mL}$ of M9 minimal media. The resuspension was diluted in the same media to an optical density at $600 \mathrm{~nm}\left(O D_{600}\right)$ of 0.2 , and serially diluted $10^{-1}, 10^{-2}, 10^{-3}$, and $10^{-4}$-fold. A total of $2 \mu \mathrm{L}$ of each dilution was spotted on $\mathrm{M} 9$ agar plates containing $\mathrm{Cm}$ with various concentrations of arabinose, or without inducer. To assess the effect of antitoxin expression on E. coli growth, serial dilutions of BL21(DE3) cells harboring PET21c or pET21c-antitoxin were prepared as described above and spotted on M9 agar plates containing Amp with or without IPTG.

For the neutralization assay, the serially diluted samples of BL21 (DE3) harboring plasmid pairs (pBAD33/pET21c, pBAD33-toxin/ pET21c, pBAD33/pET21c-antitoxin, or pBAD33-toxin/pET21cantitoxin) were prepared and spotted on M9 agar plates containing $\mathrm{Amp}$ and $\mathrm{Cm}$ with or without inducers. For the neutralization assay for the BoVapBC1 TA system in liquid medium, overnight cultures of BL21(DE3) transformants with plasmid pairs (pBAD33/pET21c, pBAD33-BoVapC1/pET21c, pBAD33/pET2 1c-BoVapB1, or pBAD33-BoVapC1/pET21c-BoVapB1) were di- luted 100-fold in M9 minimal media supplemented with Amp and $\mathrm{Cm}$. After incubation at $37^{\circ} \mathrm{C}$ to the early exponential phase, the cultures were diluted fivefold with the same medium, and then inducers were added as follows: $0.4 \%$ arabinose, $0.1 \mathrm{mM} \mathrm{IPTG}$, or both. The diluted cultures were incubated at $18^{\circ} \mathrm{C}$ for $24 \mathrm{~h}$ and continuously diluted fivefold every $6 \mathrm{~h}$ in fresh $\mathrm{M} 9$ minimal medium with or without inducers, and $\mathrm{OD}_{600}$ was measured.

\section{Live/dead cell staining for microscopy}

Overnight cultures of $\mathrm{BL21(DE3)}$ cells harboring pBAD33 or pBAD33-BoVapC1 were diluted 100-fold in M9 minimal media containing $\mathrm{Cm}$ at $37^{\circ} \mathrm{C}$, followed by cultivation to the early exponential phase. The cell cultures were diluted fivefold in fresh M9 media supplemented with $\mathrm{Cm}$ and $0.4 \%$ arabinose and incubated at $18^{\circ} \mathrm{C}$ for $24 \mathrm{~h}$. A total of $1.5 \mathrm{~mL}$ of cell cultures at the $\mathrm{OD}_{600}$ of 0.8 were harvested by centrifugation at each point in time $(0,3,6,12$, and $24 \mathrm{~h})$ and washed twice with $1.2 \mathrm{~mL}$ of $0.85 \% \mathrm{NaCl}$. The pellets were resuspended in $1.2 \mathrm{~mL}$ of $0.85 \% \mathrm{NaCl}$. Then, the samples were stained using LIVE/DEAD BacLight Bacterial Viability Kit (Thermo Fisher Scientific), following the manufacturer's instructions. Briefly, $12 \mu \mathrm{L}$ of the diluted dye mixture of SYTO9 and PI was added to each bacterial suspension. After incubation at room temperature in the dark for $15 \mathrm{~min}$, the bacterial suspensions were concentrated 10-fold. A total of $5 \mu \mathrm{L}$ of the stained bacterial suspension was placed between the slide and cover glasses, and cells were observed with an Axio Observer (Zeiss) at 1000× magnification.

To quantitate each staining, the bacterial suspensions were diluted to an $\mathrm{OD}_{600}$ of 0.2 in $1 \mathrm{~mL}$ with $0.85 \% \mathrm{NaCl}$. Equal volumes of SYTO9 and PI dyes were mixed beforehand, following which $3 \mu \mathrm{L}$ of dye mixture was added to each bacterial suspension. The stained samples were incubated at room temperature in the dark for $15 \mathrm{~min}$ and transferred to a cuvette. Fluorescence intensity was determined with a fluorescence spectrophotometer (Hitachi F-7000) at $470 \mathrm{~nm}$ for excitation and wavelength spectrums of 510-540 nm (for SYTO9) and 620-650 nm (for PI) for emission. The percentage of live bacteria was calculated by dividing the SYTO9 intensity into the sum of SYTO9 and PI intensities.

\section{Growth resumption test}

Overnight cultures of BL21(DE3) cells cotransformed with pET21c-BoVapB1 and pBAD33-BoVapC1 were diluted 100-fold in $\mathrm{M} 9$ media supplemented with $\mathrm{Amp}$ and $\mathrm{Cm}$ and incubated at $37^{\circ} \mathrm{C}$ to the early exponential phase. Then, the cultures were diluted fivefold into fresh $\mathrm{M} 9$ media with or without $0.4 \%$ arabinose, and further incubated at $18^{\circ} \mathrm{C}$ for $60 \mathrm{~h}$. At $24 \mathrm{~h}$ after arabinose addition, the cells were harvested by centrifugation and resuspended in the same volume of M9 minimal medium supplemented with $0.1 \mathrm{mM}$ IPTG. OD 600 was measured at every $10 \mathrm{~h}$.

\section{Quantitative real time PCR (qRT-PCR) analysis}

BL21(DE3) cells harboring pBAD33 or pBAD33-BoVapC1, grown to the early exponential phase, were diluted fivefold in M9 minimal media supplemented with $\mathrm{Cm}$ and $0.4 \%$ arabinose and incubated at $37^{\circ} \mathrm{C}$ or $18^{\circ} \mathrm{C}$ for $3 \mathrm{~h}$. For the neutralized cells, BL21(DE3) cells cotransformed with pBAD33/pET21c, pBAD33-BoVapC1/ 
pET21c, pBAD33/pET21c-BoVapB1, or pBAD33-BoVapC1/ pET21c-BoVapB1 were grown to the early exponential phase and diluted fivefold in M9 minimal media supplemented with Amp, $\mathrm{Cm}, 0.4 \%$ of arabinose, and $0.1 \mathrm{mM} \mathrm{IPTG}$, followed by incubation at $18^{\circ} \mathrm{C}$ for $3 \mathrm{~h}$. At the indicated time point, $2 \mathrm{~mL}$ of cell cultures for $\mathrm{OD}_{600}$ of 1.0 were harvested by centrifugation.

Total RNA was extracted using the hot phenol method with some modification (Sarmientos et al. 1983). BL21(DE3) cells were grown to $\mathrm{OD}_{600}$ of 1.0 , and $1.5 \mathrm{~mL}$ of culture was harvested by centrifugation at 13,000 rpm for $1 \mathrm{~min}$. The cell pellets were resuspended in $500 \mu \mathrm{L}$ of Solution A [ $20 \mathrm{mM}$ sodium acetate, $10 \mathrm{mM}$ ethylenediaminetetraacetic acid (EDTA), 0.5\% sodium dodecyl sulfate (SDS)], and mixed with equal volumes of phenol $(\mathrm{pH} 4.3)$. After incubation at $60^{\circ} \mathrm{C}$ for $10 \mathrm{~min}$ and on ice for $5 \mathrm{~min}$, centrifugation at $13,000 \mathrm{rpm}$ was performed to remove the phenol. The supernatants were transferred to new tubes and mixed with $50 \mu \mathrm{L}$ of $3 \mathrm{M}$ sodium acetate $(\mathrm{pH} \mathrm{5.2)}$ and $1 \mathrm{~mL}$ of $100 \%$ cold ethanol. Following incubation at $-20^{\circ} \mathrm{C}$ for $1 \mathrm{~h}$, ethanol was removed by centrifugation at $13,000 \mathrm{rpm}$ for $10 \mathrm{~min}$ at $4^{\circ} \mathrm{C}$. The pellets were dissolved in Solution A without SDS and precipitated with ethanol once more. Ethanol was removed by centrifugation, following which the pellets were washed with $75 \%$ ethanol. Finally, RNAs were dissolved in $100 \mu \mathrm{L}$ of diethylpyrocarbonate (DEPC)-treated water. The concentration and purity of the RNA were determined using a NanoDrop One ${ }^{C}$ Spectrophotometer (Thermo Fisher Scientific), and the quality of RNA was validated by agarose gel electrophoresis. DNA contamination was removed by treatment with recombinant DNase I (RNase-free) (TaKaRa) according to the manufacturer's protocol. Then, cDNA synthesis was carried out using BioFACT RT Kit and $1 \mu \mathrm{g}$ of total RNA. The qRT-PCR reaction was carried out as previously described (Choi et al. 2020). The recA gene served as an endogenous reference, and relative quantification values were calculated using the comparative $C_{T}$ method (Livak and Schmittgen 2001). The primers used for qRT-PCR analysis are listed in Supplemental Table S1. The level of tRNA was examined using primer sets to amplify the anticodon stem and loop regions.

\section{Northern blotting}

A total of $20 \mu \mathrm{g}$ of total RNAs, denatured with formamide by heating at $70^{\circ} \mathrm{C}$ for $10 \mathrm{~min}$, were separated on $15 \%$ denaturing polyacrylamide gel containing $8 \mathrm{M}$ urea in $1 \times$ TBE [45 mM Tris-borate (pH 8.3), $1 \mathrm{mM}$ EDTA]. The gel was run at $100 \mathrm{~V}$ for $\sim 2.5 \mathrm{~h}$ until the bromophenol blue dye front reached to $0.5 \mathrm{~cm}$ above the bottom of the gel. Then, the RNAs were transferred to a nylon membrane (Hybond N+, Amersham) by electroblotting using Bio-Rad SemiDry electrophoretic transfer cell at constant $20 \mathrm{~V}$ for $1 \mathrm{~h}$. After transfer, the membrane was cross-linked by exposure to ultraviolet light ( $254 \mathrm{~nm}$ ) at $120 \mathrm{~mJ} / \mathrm{cm}^{2}$ for 1 min using CL-1000 UV crosslinker (UVP Inc.). Next, the membrane was prehybridized with hybridization buffer [100 mM sodium phosphate $(\mathrm{pH} 7.2)$, $0.2 \mathrm{mM}$ EDTA, 1\% SDS, $1 \mathrm{mg} / \mathrm{ml}$ bovine serum albumin] with $50 \mu \mathrm{g} / \mathrm{mL}$ denatured salmon sperm DNA for $4 \mathrm{~h}$ at $65^{\circ} \mathrm{C}$. Then, the membrane was incubated at $52^{\circ} \mathrm{C}$ overnight with hybridization buffer supplemented with $500 \mathrm{ng} / \mathrm{mL}$ probes labeled with biotin at both ends (Supplemental Table S1). The membrane was washed sequentially with wash buffer I [ $2 \times$ SSC, $0.1 \%$ SDS], with wash buffer II [ $1 \times$ SSC $0.1 \%$ SDS], and with $0.1 \times \mathrm{SSC}$ at $42^{\circ} \mathrm{C}$ for $15 \mathrm{~min}$ each. The biotin signals were detected using a Biotin Chromogenic Detection Kit (Thermo Fisher Scientific) following the manufacturer's instructions.

\section{Survival rate measurements}

BL21(DE3) cells harboring pET21c-BoVapB1 were transformed with pBAD33 or pBAD33-BoVapC1 and grown in M9 minimal medium with $\mathrm{Amp}$ and $\mathrm{Cm}$ at $37^{\circ} \mathrm{C}$ to the early exponential phase. The cultures were diluted fivefold in $\mathrm{M} 9$ minimal media supplemented with $\mathrm{Amp}, \mathrm{Cm}$, and $0.4 \%$ arabinose and further incubated at $18^{\circ} \mathrm{C}$ for $3 \mathrm{~h}$. Then, the cells were incubated at $4^{\circ} \mathrm{C}$ for $48 \mathrm{~h}$. At the indicated time points, the cells were diluted in M9 minimal medium to an $\mathrm{OD}_{600}: 0.1$. The resuspension was further diluted $10^{-5}$-fold and plated on $\mathrm{M} 9$ agar plates with $0.1 \mathrm{mM}$ IPTG, followed by incubation at $37^{\circ} \mathrm{C}$. Colony forming units (CFU) were counted, and the survival rates were expressed as the percentage of the number of colonies in the treated samples $(3,6,12$, and $24 \mathrm{~h})$, compared with that of the untreated samples $(0 \mathrm{~h})$.

\section{Statistical analysis}

Results are presented as the mean \pm SD of three independent experiments. The data were analyzed by two-tailed $t$-tests. The statistical analyses were performed with the following significance levels: NS, nonsignificant; ( $\left.{ }^{*}\right) P<0.05$; (**) $P<0.01$; (***) $P<0.001$.

\section{SUPPLEMENTAL MATERIAL}

Supplemental material is available for this article.

\section{ACKNOWLEDGMENTS}

This work was supported by a National Research Foundation of Korea (NRF) grant funded by the Korean government (MSIT) (NRF-2018R1A2B6003179). This research was supported by the Basic Science Research Program through the National Research Foundation of Korea (NRF) funded by the Ministry of Education (NRF-2020R1A6A3A01100161).

Received April 12, 2021; accepted August 19, 2021.

\section{REFERENCES}

Aakre CD, Phung TN, Huang D, Laub MT. 2013. A bacterial toxin inhibits DNA replication elongation through a direct interaction with the $\beta$ sliding clamp. Mol Cell 52: 617-628. doi:10.1016/j.molcel .2013.10.014

Afif H, Allali N, Couturier M, Van Melderen L. 2001. The ratio between $\mathrm{CcdA}$ and $\mathrm{CcdB}$ modulates the transcriptional repression of the ccd poison-antidote system. Mol Microbiol 41: 73-82. doi:10 .1046/j.1365-2958.2001.02492.x

Agarwal S, Sharma A, Bouzeyen R, Deep A, Sharma H, Mangalaparthi KK, Datta KK, Kidwai S, Gowda H, Varadarajan R, et al. 2020. VapBC22 toxin-antitoxin system from Mycobacterium tuberculosis is required for pathogenesis and modulation of host immune response. Sci Adv 6: eaba6944. doi:10.1126/sciadv .aba6944 
Akarsu H, Bordes P, Mansour M, Bigot DJ, Genevaux P, Falquet L. 2019. TASmania: a bacterial toxin-antitoxin systems database. PLoS Comput Biol 15: e1006946. doi:10.1371/journal.pcbi .1006946

Albert RA, McGuine M, Pavlons SC, Roecker J, Bruess J, Mossman S, Sun S, King M, Hong S, Farrance CE, et al. 2019. Bosea psychrotolerans sp. nov., a psychrotrophic alphaproteobacterium isolated from Lake Michigan water. Int J Syst Evol Microbiol 69: 13761383. doi:10.1099/ijsem.0.003319

Arcus VL, McKenzie JL, Robson J, Cook GM. 2011. The PIN-domain ribonucleases and the prokaryotic $\mathrm{VapBC}$ toxin-antitoxin array. Protein Eng Des Sel 24: 33-40. doi:10.1093/protein/gzq081

Black DS, Irwin B, Moyed HS. 1994. Autoregulation of hip, an operon that affects lethality due to inhibition of peptidoglycan or DNA synthesis. J Bacteriol 176: 4081-4091. doi:10.1128/Jb.176.13 .4081-4091.1994

Boggild A, Sofos N, Andersen KR, Feddersen A, Easter AD, Passmore LA, Brodersen DE. 2012. The crystal structure of the intact $E$. coli RelBE toxin-antitoxin complex provides the structural basis for conditional cooperativity. Structure 20: 1641-1648. doi:10.1016/j.str.2012.08.017

Brandi A, Giangrossi M, Paoloni S, Spurio R, Giuliodori AM, Pon CL, Gualerzi CO. 2019. Transcriptional and post-transcriptional events trigger de novo infB expression in cold stressed Escherichia coli. Nucleic Acids Res 47: 4638-4651. doi:10.1093/nar/gkz187

Brantl S, Jahn N. 2015. sRNAs in bacterial type I and type III toxin-antitoxin systems. FEMS Microbiol Rev 39: 413-427. doi:10.1093/ femsre/fuv003

Bruno S, Coppola D, di Prisco G, Giordano D, Verde C. 2019. Enzymes from marine polar regions and their biotechnological applications. Mar Drugs 17: 544. doi:10.3390/md17100544

Cataudella I, Trusina A, Sneppen K, Gerdes K, Mitarai N. 2012. Conditional cooperativity in toxin-antitoxin regulation prevents random toxin activation and promotes fast translational recovery. Nucleic Acids Res 40: 6424-6434. doi:10.1093/nar/gks297

Cheverton AM, Gollan B, Przydacz M, Wong CT, Mylona A, Hare SA, Helaine S. 2016. A Salmonella toxin promotes persister formation through acetylation of tRNA. Mol Cell 63: 86-96. doi:10.1016/j .molcel.2016.05.002

Choi E, Jeon H, Oh C, Hwang J. 2020. Elucidation of a novel role of YebC in surface polysaccharides regulation of Escherichia coli bipA-deletion. Front Microbiol 11: 597515. doi:10.3389/fmicb .2020 .597515

Cline SD, Saleem S, Daines DA. 2012. Regulation of the vapBC-1 toxin-antitoxin locus in nontypeable Haemophilus influenzae. PLoS One 7: e32199. doi:10.1371/journal.pone.0032199

Cooper CR, Daugherty AJ, Tachdjian S, Blum PH, Kelly RM. 2009. Role of vapBC toxin-antitoxin loci in the thermal stress response of Sulfolobus solfataricus. Biochem Soc Trans 37: 123-126. doi:10.1042/Bst0370123

Cruz JW, Sharp JD, Hoffer ED, Maehigashi T, Vvedenskaya IO, Konkimalla A, Husson RN, Nickels BE, Dunham CM, Woychik NA. 2015. Growth-regulating Mycobacterium tuberculosis VapC-mt4 toxin is an isoacceptor-specific tRNase. Nat Commun 6: 7480 . doi: $10.1038 /$ ncomms 8480

Das SK, Mishra AK, Tindall BJ, Rainey FA, Stackebrandt E. 1996. Oxidation of thiosulfate by a new bacterium, Bosea thiooxidans (strain Bl-42) gen nov, sp nov: analysis of phylogeny based on chemotaxonomy and $16 \mathrm{~S}$ ribosomal DNA sequencing. Int J Syst Bacteriol 46: 981-987. doi:10.1099/00207713-46-4-981

de la Hoz AB, Ayora S, Sitkiewicz I, Fernandez S, Pankiewicz R, Alonso JC, Ceglowski P. 2000. Plasmid copy-number control and better-than-random segregation genes of pSM19035 share a common regulator. Proc Natl Acad Sci 97: 728-733. doi:10 $.1073 /$ pnas. 97.2 .728
Dienemann C, Boggild A, Winther KS, Gerdes K, Brodersen DE. 2011. Crystal structure of the VapBC toxin-antitoxin complex from Shigella flexneri reveals a hetero-octameric DNA-binding assembly. J Mol Biol 414: 713-722. doi:10.1016/j.jmb.2011.10.024

Ducret A, Quardokus EM, Brun YV. 2016. MicrobeJ, a tool for high throughput bacterial cell detection and quantitative analysis. Nat Microbiol 1: 16077. doi:10.1038/Nmicrobiol.2016.77

Eroshenko DV, Polyudova TV, Pyankova AA. 2020. VapBC and MazEF toxin/antitoxin systems in the regulation of biofilm formation and antibiotic tolerance in nontuberculous mycobacteria. Int $J$ Mycobacteriol 9: 156-166. doi:10.4103/ijmy.ijmy_61_20

Feller G. 2013. Psychrophilic enzymes: from folding to function and biotechnology. Scientifica (Cairo) 2013: 512840. doi:10.1155/ 2013/512840

Fineran PC, Blower TR, Foulds IJ, Humphreys DP, Lilley KS, Salmond GP. 2009. The phage abortive infection system, ToxIN, functions as a protein-RNA toxin-antitoxin pair. Proc Natl Acad Sci 106: 894-899. doi:10.1073/pnas.0808832106

Fozo EM, Makarova KS, Shabalina SA, Yutin N, Koonin EV, Storz G. 2010. Abundance of type I toxin-antitoxin systems in bacteria: searches for new candidates and discovery of novel families. Nucleic Acids Res 38: 3743-3759. doi:10.1093/nar/gkq054

Garcia-Pino A, Balasubramanian S, Wyns L, Gazit E, De Greve H, Magnuson RD, Charlier D, van Nuland NA, Loris R. 2010. Allostery and intrinsic disorder mediate transcription regulation by conditional cooperativity. Cell 142: 101-111. doi:10.1016/j .cell.2010.05.039

Gerdes K, Rasmussen PB, Molin S. 1986. Unique type of plasmid maintenance function: postsegregational killing of plasmid-free cells. Proc Natl Acad Sci 83: 3116-3120. doi:10.1073/pnas.83 .10 .3116

Gerdes K, Christensen SK, Lobner-Olesen A. 2005. Prokaryotic toxinantitoxin stress response loci. Nat Rev Microbiol 3: 371-382. doi:10.1038/nrmicro1147

Giangrossi M, Brandi A, Giuliodori AM, Gualerzi CO, Pon CL. 2007. Cold-shock-induced de novo transcription and translation of infA and role of IF1 during cold adaptation. Mol Microbiol 64: 807821. doi:10.1111/j.1365-2958.2007.05699.x

Giuliodori AM, Brandi A, Giangrossi M, Gualerzi CO, Pon CL. 2007. Cold-stress-induced de novo expression of infC and role of IF3 in cold-shock translational bias. RNA 13: 1355-1365. doi:10 $.1261 /$ rna. 455607

Gupta A, Venkataraman B, Vasudevan M, Gopinath Bankar K. 2017. Co-expression network analysis of toxin-antitoxin loci in Mycobacterium tuberculosis reveals key modulators of cellular stress. Sci Rep 7: 5868. doi:10.1038/s41598-017-06003-7

Guzman LM, Belin D, Carson MJ, Beckwith J. 1995. Tight regulation, modulation, and high-level expression by vectors containing the arabinose PBAD promoter. J Bacteriol 177: 4121-4130. doi:10 $.1128 / \mathrm{jb} .177 .14 .4121-4130.1995$

Habib G, Zhu Q, Sun B. 2018. Bioinformatics and functional assessment of toxin-antitoxin systems in Staphylococcus aureus. Toxins (Basel) 10: 473. doi:10.3390/toxins 10110473

Hayes F. 2003. Toxins-antitoxins: plasmid maintenance, programmed cell death, and cell cycle arrest. Science 301: 1496-1499. doi:10 $.1126 /$ science. 1088157

Helaine S, Cheverton AM, Watson KG, Faure LM, Matthews SA, Holden DW. 2014. Internalization of Salmonella by macrophages induces formation of nonreplicating persisters. Science 343: 204-208. doi:10.1126/science.1244705

Horesh G, Fino C, Harms A, Dorman MJ, Parts L, Gerdes K, Heinz E, Thomson NR. 2020. Type II and type IV toxin-antitoxin systems show different evolutionary patterns in the global Klebsiella pneumoniae population. Nucleic Acids Res 48: 4357-4370. doi:10 $.1093 /$ nar/gkaa198 
Ishii S, Kuroki K, Imamoto F. 1984. tRNA ${ }^{\text {Metf2 }}$ gene in the leader region of the nusA operon in Escherichia coli. Proc Natl Acad Sci 81: 409413. doi:10.1073/pnas.81.2.409

Kang S, Han SR, Oh TJ, Park H. 2016. Complete genome sequence of thiosulfate-oxidizing Bosea sp strain PAMC26642 isolated from an Arctic lichen. J Biotechnol 223: 38-39. doi:10.1016/j.jbiotec.2016 .02 .033

Kang SM, Kim DH, Jin C, Lee BJ. 2018. A systematic overview of type II and III toxin-antitoxin systems with a focus on druggability. Toxins (Basel) 10: 515. doi:10.3390/toxins10120515

Kapoor S, Das G, Varshney U. 2011. Crucial contribution of the multiple copies of the initiator tRNA genes in the fidelity of tRNA ${ }^{\mathrm{fMet}}$ selection on the ribosomal P-site in Escherichia coli. Nucleic Acids Res 39: 202-212. doi:10.1093/nar/gkq760

Kato F, Yoshizumi S, Yamaguchi Y, Inouye M. 2019. Genome-wide screening for identification of novel toxin-antitoxin systems in Staphylococcus aureus. Appl Environ Microbiol 85: e00915-19. doi:10.1128/AEM.00915-19

Kedzierska B, Hayes F. 2016. Emerging roles of toxin-antitoxin modules in bacterial pathogenesis. Molecules 21: 790. doi:10.3390/ molecules21060790

Kenri T, Imamoto F, Kano Y. 1994. Three tandemly repeated structural genes encoding tRNA ${ }^{\text {f1Met }}$ in the metZ operon of Escherichia coli K-12. Gene 138: 261-262. doi:10.1016/0378-1119(94)90821-4

Korch SB, Hill TM. 2006. Ectopic overexpression of wild-type and mutant hipA genes in Escherichia coli: effects on macromolecular synthesis and persister formation. J Bacteriol 188: 3826-3836. doi:10 .1128/JB.01740-05

La Scola B, Mallet MN, Grimont PAD, Raoult D. 2003. Bosea eneae sp. nov., Bosea massiliensis sp. nov. and Bosea vestrisii sp. nov., isolated from hospital water supplies, and emendation of the genus Bosea (Das et al. 1996). Int J Syst Evol Microbiol 53: 15-20. doi:10.1099/ijs.0.02127-0

Lehnherr H, Yarmolinsky MB. 1995. Addiction protein Phd of plasmid prophage $\mathrm{P} 1$ is a substrate of the ClpXP serine protease of Escherichia coli. Proc Natl Acad Sci 92: 3274-3277. doi: 10 .1073/pnas.92.8.3274

Leplae R, Geeraerts D, Hallez R, Guglielmini J, Dreze P, Van Melderen L. 2011. Diversity of bacterial type II toxin-antitoxin systems: a comprehensive search and functional analysis of novel families. Nucleic Acids Res 39: 5513-5525. doi:10.1093/nar/ gkr131

Levin-Reisman I, Ronin I, Gefen O, Braniss I, Shoresh N, Balaban NQ. 2017. Antibiotic tolerance facilitates the evolution of resistance. Science 355: 826-830. doi:10.1126/science.aaj2191

Li GY, Zhang Y, Inouye M, Ikura M. 2008. Structural mechanism of transcriptional autorepression of the Escherichia coli RelB/RelE antitoxin/toxin module. J Mol Biol 380: 107-119. doi:10.1016/j.jmb 2008.04.039

Li M, Gong L, Cheng F, Yu H, Zhao D, Wang R, Wang T, Zhang S, Zhou J, Shmakov SA, et al. 2021. Toxin-antitoxin RNA pairs safeguard CRISPR-Cas systems. Science 372: eabe5601. doi:10 .1126/science.abe5601

Livak KJ, Schmittgen TD. 2001. Analysis of relative gene expression data using real-time quantitative PCR and the $2^{-\Delta \Delta C T}$ method. Methods 25: 402-408. doi:10.1006/meth.2001.1262

Lobato-Marquez D, Diaz-Orejas R, Garcia-del Portillo F. 2016. Toxinantitoxins and bacterial virulence. FEMS Microbiol Rev 40: 592 609. doi:10.1093/femsre/fuw022

Lopes APY, Lopes LM, Fraga TR, Chura-Chambi RM, Sanson AL, Cheng E, Nakajima E, Morganti L, Martins EAL. 2014. VapC from the leptospiral VapBC toxin-antitoxin module displays ribonuclease activity on the initiator tRNA. PLoS One 9: e101678. doi:10 .1371/journal.pone.0101678
Maezato Y, Daugherty A, Dana K, Soo E, Cooper C, Tachdjian S, Kelly RM, Blum P. 2011. VapC6, a ribonucleolytic toxin regulates thermophilicity in the crenarchaeote Sulfolobus solfataricus. RNA 17: 1381-1392. doi:10.1261/rna.2679911

Magnuson R, Yarmolinsky MB. 1998. Corepression of the P1 addiction operon by Phd and Doc. J Bacteriol 180: 6342-6351. doi:10.1128/ JB.180.23.6342-6351.1998

Masuda H, Tan Q, Awano N, Wu KP, Inouye M. 2012. YeeU enhances the bundling of cytoskeletal polymers of MreB and FtsZ, antagonizing the CbtA (YeeV) toxicity in Escherichia coli. Mol Microbiol 84: 979-989. doi:10.1111/j.1365-2958.2012.08068.x

McKenzie JL, Robson J, Berney M, Smith TC, Ruthe A, Gardner PP, Arcus VL, Cook GM. 2012. A VapBC toxin-antitoxin module is a posttranscriptional regulator of metabolic flux in mycobacteria. $J$ Bacteriol 194: 2189-2204. doi:10.1128/Jb.06790-11

Mikkelsen ND, Gerdes K. 1997. Sok antisense RNA from plasmid R1 is functionally inactivated by RNase $\mathrm{E}$ and polyadenylated by poly(A) polymerase I. Mol Microbiol 26: 311-320. doi:10.1046/j.13652958.1997.5751936.x

Mruk I, Kobayashi I. 2014. To be or not to be: regulation of restrictionmodification systems and other toxin-antitoxin systems. Nucleic Acids Res 42: 70-86. doi:10.1093/nar/gkt711

Muller P, Jahn N, Ring C, Maiwald C, Neubert R, Meissner C, Brantl S. 2016. A multistress responsive type I toxin-antitoxin system: bsrE/ SR5 from the B. subtilis chromosome. RNA Biol 13: 511-523. doi:10.1080/15476286.2016.1156288

Muthuramalingam M, White JC, Bourne CR. 2016. Toxin-antitoxin modules are pliable switches activated by multiple protease pathways. Toxins (Basel) 8: 214. doi:10.3390/toxins8070214

Ogura T, Hiraga S. 1983. Mini-F plasmid genes that couple host-cell division to plasmid proliferation. Proc Natl Acad Sci 80: 47844788. doi:10.1073/pnas.80.15.4784

Otsuka Y, Yonesaki T. 2012. Dmd of bacteriophage T4 functions as an antitoxin against Escherichia coli LsoA and RnIA toxins. Mol Microbiol 83: 669-681. doi:10.1111/j.1365-2958.2012.07975.x

Overgaard M, Borch J, Jorgensen MG, Gerdes K. 2008. Messenger RNA interferase RelE controls relBE transcription by conditional cooperativity. Mol Microbiol 69: 841-857. doi:10.1111/j.13652958.2008.06313.x

Pandey DP, Gerdes K. 2005. Toxin-antitoxin loci are highly abundant in free-living but lost from host-associated prokaryotes. Nucleic Acids Res 33: 966-976. doi:10.1093/nar/gki201

Pullinger GD, Lax AJ. 1992. A Salmonella dublin virulence plasmid locus that affects bacterial growth under nutrient-limited conditions. Mol Microbiol 6: 1631-1643. doi:10.1111/j.1365-2958.1992 .tb00888.x

Ramage HR, Connolly LE, Cox JS. 2009. Comprehensive functional analysis of Mycobacterium tuberculosis toxin-antitoxin systems: implications for pathogenesis, stress responses, and evolution. PLoS Genet 5: e1000767. doi:10.1371/journal.pgen.1000767

Ren D, Walker AN, Daines DA. 2012. Toxin-antitoxin loci vapBC-1 and vapXD contribute to survival and virulence in nontypeable Haemophilus influenzae. BMC Microbiol 12: 263. doi:10.1186/ 1471-2180-12-263

Rengarajan J, Bloom BR, Rubin EJ. 2005. Genome-wide requirements for Mycobacterium tuberculosis adaptation and survival in macrophages. Proc Natl Acad Sci 102: 8327-8332. doi:10.1073/pnas 0503272102

Reuter JS, Mathews DH. 2010. RNAstructure: software for RNA secondary structure prediction and analysis. BMC Bioinformatics 11: 129. doi:10.1186/1471-2105-11-129

Roberts RC, Strom AR, Helinski DR. 1994. The parDE operon of the broad-host-range plasmid RK2 specifies growth inhibition associated with plasmid loss. J Mol Biol 237: 35-51. doi:10.1006/jmbi .1994 .1207 
Rocker A, Meinhart A. 2015. A cis-acting antitoxin domain within the chromosomal toxin-antitoxin module EzeT of Escherichia coli quenches toxin activity. Mol Microbiol 97: 589-604. doi:10 $.1111 / \mathrm{mmi} .13051$

Rycroft JA, Gollan B, Grabe GJ, Hall A, Cheverton AM, LarrouyMaumus G, Hare SA, Helaine S. 2018. Activity of acetyltransferase toxins involved in Salmonella persister formation during macrophage infection. Nat Commun 9: 1993. doi:10.1038/s41467018-04472-6

Santos-Sierra S, Pardo-Abarrio C, Giraldo R, Diaz-Orejas R. 2002. Genetic identification of two functional regions in the antitoxin of the parD killer system of plasmid R1. FEMS Microbiol Lett 206: 115-119. doi:10.1016/S0378-1097(01)00482-7

Sarmientos P, Sylvester JE, Contente S, Cashel M. 1983. Differential stringent control of the tandem E. coli ribosomal RNA promoters from the rrnA operon expressed in vivo in multicopy plasmids. Cell 32: 1337-1346. doi:10.1016/0092-8674(83)90314-8

Senissar M, Manav MC, Brodersen DE. 2017. Structural conservation of the PIN domain active site across all domains of life. Protein Sci 26: 1474-1492. doi:10.1002/pro.3193

Sevin EW, Barloy-Hubler F. 2007. RASTA-Bacteria: a web-based tool for identifying toxin-antitoxin loci in prokaryotes. Genome Biol 8: R155. doi:10.1186/gb-2007-8-8-r155

Sharma A, Chattopadhyay G, Chopra P, Bhasin M, Thakur C, Agarwal S, Ahmed S, Chandra N, Varadarajan R, Singh R. 2020. VapC21 toxin contributes to drug-tolerance and interacts with non-cognate VapB32 antitoxin in Mycobacterium tuberculosis. Front Microbiol 11: 2037. doi:10.3389/fmicb.2020.02037

Short FL, Akusobi C, Broadhurst WR, Salmond GPC. 2018. The bacterial type III toxin-antitoxin system, ToxIN, is a dynamic protein-RNA complex with stability-dependent antiviral abortive infection activity. Sci Rep 8: 1013. doi:10.1038/s41598-017-18696-x

Singh R, Barry CE III, Boshoff HI. 2010. The three RelE homologs of Mycobacterium tuberculosis have individual, drug-specific effects on bacterial antibiotic tolerance. J Bacteriol 192: 1279-1291. doi:10.1128/JB.01285-09

Smith JA, Magnuson RD. 2004. Modular organization of the phd repressor/antitoxin protein. J Bacteriol 186: 2692-2698. doi:10 .1128/Jb.186.9.2692-2698.2004

Srivastava A, Garg S, Jain R, Ayana R, Kaushik H, Garg L, Pati S, Singh S. 2019. Identification and functional characterization of a bacterial homologue of Zeta toxin in Leishmania donovani. FEBS Lett 593: 1223-1235. doi:10.1002/1873-3468.13429

Stocks SM. 2004. Mechanism and use of the commercially available viability stain, BacLight. Cytom Part A 61a: 189-195. doi:10 .1002/cyto.a.20069

Stothard P, Wishart DS. 2005. Circular genome visualization and exploration using CGView. Bioinformatics 21: 537-539. doi:10 .1093/bioinformatics/bti054

Tam JE, Kline BC. 1989. The F-plasmid ccd autorepressor is a complex of $\mathrm{CcdA}$ and $\mathrm{CcdB}$ proteins. Mol Gen Genet 219: 26-32. doi:10 $.1007 / \mathrm{BfO0261153}$

Tamman H, Ainelo A, Ainsaar K, Horak R. 2014. A moderate toxin, GraT, modulates growth rate and stress tolerance of Pseudomonas putida. J Bacteriol 196: 157-169. doi:10.1128/JB $.00851-13$

Tandon H, Sharma A, Sandhya S, Srinivasan N, Singh R. 2019. Mycobacterium tuberculosis Rv0366c-Rv0367c encodes a non-canonical PezAT-like toxin-antitoxin pair. Sci Rep 9: 1163. doi:10 .1038/s41598-018-37473-y

Tiwari P, Arora G, Singh M, Kidwai S, Narayan OP, Singh R. 2015. MazF ribonucleases promote Mycobacterium tuberculosis drug tolerance and virulence in guinea pigs. Nat Commun 6: 6059. doi:10 .1038/ncomms7059
Trueba FJ, van Spronsen EA, Traas J, Woldringh CL. 1982. Effects of temperature on the size and shape of Escherichia coli cells. Arch Microbiol 131: 235-240. doi:10.1007/BF00405885

Van Melderen L, De Bast MS. 2009. Bacterial toxin-antitoxin systems: more than selfish entities? PLoS Genet 5: e1000437. doi:10.1371/ journal.pgen.1000437

Van Melderen L, Bernard P, Couturier N. 1994. Lon-dependent proteolysis of CcdA is the key control for activation of CcdB in plasmidfree segregant bacteria. Mol Microbiol 11: 1151-1157. doi:10 $.1111 / j .1365-2958.1994 . t b 00391 . x$

Walling LR, Butler JS. 2018. Homologous VapC toxins inhibit translation and cell growth by sequence-specific cleavage of tRNA ${ }^{\mathrm{fMet}} . J$ Bacteriol 200: e00582-17. doi:10.1128/JB.00582-17

Walling LR, Butler JS. 2019. Toxins targeting transfer RNAs: translation inhibition by bacterial toxin-antitoxin systems. Wiley Interdiscip Rev RNA 10: e1506. doi:10.1002/wrna.1506

Wang XX, Lord DM, Cheng HY, Osbourne DO, Hong SH, SanchezTorres V, Quiroga C, Zheng K, Herrmann T, Peti W, et al. 2012. A new type $V$ toxin-antitoxin system where mRNA for toxin GhoT is cleaved by antitoxin GhoS. Nat Chem Biol 8: 855-861. doi:10 .1038/Nchembio.1062

Winther KS, Gerdes K. 2009. Ectopic production of VapCs from Enterobacteria inhibits translation and trans-activates YoeB mRNA interferase. Mol Microbiol 72: 918-930. doi:10.1111/j .1365-2958.2009.06694.x

Winther KS, Gerdes K. 2011. Enteric virulence associated protein VapC inhibits translation by cleavage of initiator tRNA. Proc Natl Acad Sci 108: 7403-7407. doi:10.1073/pnas.1019587108

Winther KS, Gerdes K. 2012. Regulation of enteric vapBC transcription: induction by VapC toxin dimer-breaking. Nucleic Acids Res 40: 4347-4357. doi:10.1093/nar/gks029

Winther KS, Brodersen DE, Brown AK, Gerdes K. 2013. VapC20 of Mycobacterium tuberculosis cleaves the Sarcin-Ricin loop of $23 \mathrm{~S}$ rRNA. Nat Commun 4: 2796. doi:10.1038/ncomms3796

Winther K, Tree JJ, Tollervey D, Gerdes K. 2016. VapCs of Mycobacterium tuberculosis cleave RNAs essential for translation. Nucleic Acids Res 44: 9860-9871. doi:10.1093/nar/gkw781

Wu Y, Vulic M, Keren I, Lewis K. 2012. Role of oxidative stress in persister tolerance. Antimicrob Agents Chemother 56: 4922-4926. doi:10.1128/AAC.00921-12

Xie Y, Wei Y, Shen Y, Li X, Zhou H, Tai C, Deng Z, Ou HY. 2018. TADB 2.0: an updated database of bacterial type II toxin-antitoxin loci. Nucleic Acids Res 46: D749-D753. doi:10.1093/nar/gkx1033

Xu KH, Dedic E, Brodersen DE. 2016. Structural analysis of the active site architecture of the VapC toxin from Shigella flexneri. Proteins 84: 892-899. doi:10.1002/prot.25002

Yang M, Gao CH, Wang Y, Zhang H, He ZG. 2010. Characterization of the interaction and cross-regulation of three Mycobacterium tuberculosis RelBE modules. PLoS One 5: e10672. doi:10.1371/jour nal.pone.0010672

Zhang JJ, Zhang YL, Inouye M. 2003. Characterization of the interactions within the mazEF addiction module of Escherichia coli. J Biol Chem 278: 32300-32306. doi:10.1074/jbc.M304767200

Zhang S-P, Wang Q, Quan S-W, Yu X-Q, Wang Y, Guo D-D, Peng L, Feng $\mathrm{H}-\mathrm{Y}, \mathrm{He} Y-\mathrm{X}$. 2020. Type II toxin-antitoxin system in bacteria: activation, function, and mode of action. Biophys Rep 6: 68-79. doi:10.1007/s41048-020-00109-8

Zhao Y, McAnulty MJ, Wood TK. 2016. Toxin YafQ reduces Escherichia coli growth at low temperatures. PLoS One 11: e0161577. doi:10.1371/journal.pone.0161577

Zhu L, Sharp JD, Kobayashi H, Woychik NA, Inouye M. 2010. Noncognate Mycobacterium tuberculosis toxin-antitoxins can physically and functionally interact. J Biol Chem 285: 3973239738. doi:10.1074/jbc.M110.163105 

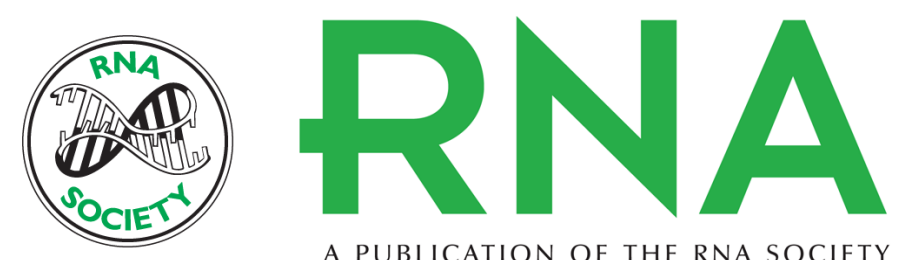

A PUBLICATION OF THE RNA SOCIETY

\section{Identification and characterization of VapBC toxin-antitoxin system in Bosea sp. PAMC 26642 isolated from Arctic lichens}

Hyerin Jeon, Eunsil Choi and Jihwan Hwang

RNA 2021 27: 1374-1389 originally published online August 24, 2021

Access the most recent version at doi:10.1261/rna.078786.121

\section{Supplemental http://rnajournal.cshlp.org/content/suppl/2021/08/24/rna.078786.121.DC1 Material}

References This article cites 107 articles, 29 of which can be accessed free at: http://rnajournal.cshlp.org/content/27/11/1374.full.html\#ref-list-1

Open Access Freely available online through the RNA Open Access option.

Creative This article, published in RNA, is available under a Creative Commons License Commons (Attribution 4.0 International), as described at

License http://creativecommons.org/licenses/by/4.0/.

Email Alerting Receive free email alerts when new articles cite this article - sign up in the box at the Service top right corner of the article or click here.

\section{|||||||| Providing Precise Solutions for your research.}

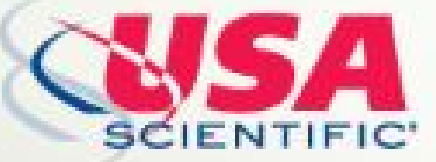

To subscribe to $R N A$ go to:

http://rnajournal.cshlp.org/subscriptions

(C) 2021 Jeon et al.; Published by Cold Spring Harbor Laboratory Press for the RNA Society 